Historic, Archive Document

Do not assume content reflects current scientific knowledge, policies, or practices. 

62.39

LIBRARY

$\star$ JUN 141920

\section{SEASON 1916}

Wholesale Price List for

Nurserymen, Florists and Dealers

The New England Nurseries Co. Bedford, Massachusetts

Telephone, Lexington 274

Everything in

HARLAN P. KELSEY, Sec.

Joint Nomenclature Committee

First-Class Matter SALEM, MASS.

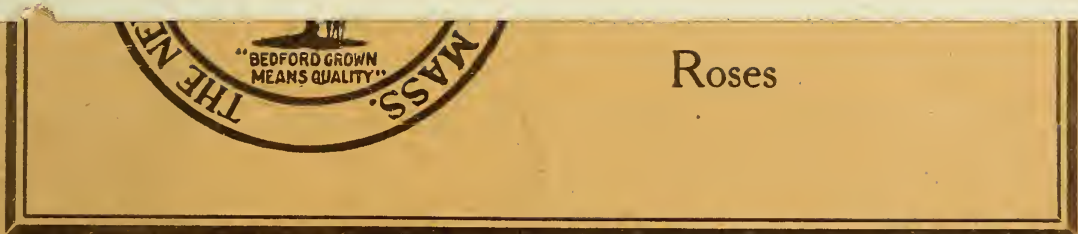




\section{Information to Customers}

Prices given in this Catalog cancel all previous quotations.

DIRECTIONS FOR SHIPPING.-Parties ordering are requested tc state explicitly the mode of conveyance by which they desire their stock forwarded. When no route is designated, we exercise our judgment; but in no case do we assume any responsibility after the packages are shipped, unless for our own mistakes. When losses occur by detention, claims should at once be made on the forwarder.

CREDIT.-We extend credit only to regular customers and parties known to us, unless satisfactory reference accompanies order.

CASH WITH ORDER.-We decline to ship goods "Collect on Delivery," unless remittance be made' on account to guarantee acceptance. We will allow a discount of 2 per cent. on all orders accompanied by cash.

PRICES AND PACKKING.-A reasonable advance will be charged where smaller quantities are ordered than those quoted in this list. Twenty-five will be furnished at hundred rate and five at rate per ten. Our prices do not include packing. On trees, shrubs, etc., packed in boxes and bales, there will be an additional charge for material actually consumed, as follows:

Boxes (including packing) $12 \mathrm{ft}$. long by $30 \mathrm{in}$. ends........\$3.50

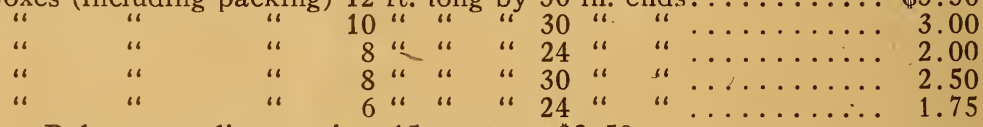

Bales, according to size, 15 cents to $\$ 2.50$. Station.

No charge is made for cartage from the Nursery to the Railroad

GENERAL CATALOG.-We shall be pleased to mail free a copy of our Illustrated General Catalog to all who indicate a desire for it: The book contains reliable information and descriptions of Trees, Shrubs and Plants hardy in New England. It will be mailed only upon request.

\section{QUALITY OF STOCK}

The stock offered in this list is strictly first-class, and, we believe, absolutely free from all injurious insects or diseases.

CERTIFICATE OF INSPECTION.-Both State and Federal, accompanies every shipment.

THE NEW ENGLAND NURSERIES CO.

Tel. Lexington 274 .

Bedford, Massachusetts.

\section{NON-WARRANTY}

We give no warranty expressed oi implied as to description, quality, productiveness or any other matter of any Nursery Stock; Bulbs or Plants we sell. No complaints will be considered that are not made within five days after receipt of stock.

THE NEW ENGLAND NURSERIES CO. 


\section{Contents}

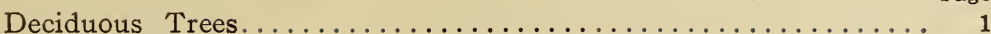

Evergreen Trees............................... 5

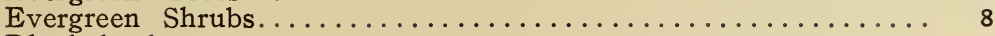

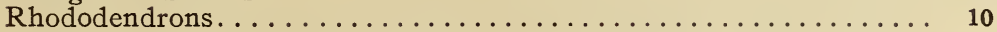

Deciduous Shrubs........................... 10

Globe or Ball-shaped Privet......................... 12

French or Hybrid Lilacs....................... 15

Standard Shrubs............................ 15

Vines and Climbing Shrubs..................... 15

Herbaceous Perennials, Grasses and Ferns.............. 16

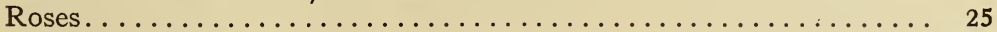

Fruit Trees and Small Fruits.................... 28

The prices quoted in this catalog are for TRANSPLANTED and "BEDFORD GROWN QUALITY" stock.

\section{Ornamental Deciduous Trees}

Acer dasycarpum (Silver Maple) 8 to $10 \mathrm{ft} \ldots \ldots . . . . . . . . .10$

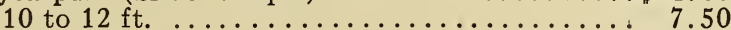

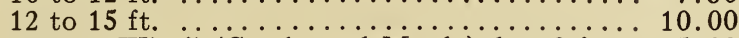

" dasycarpum Wierii (Cut-leaved Maple) 6 to $8 \mathrm{ft}$... 5.00

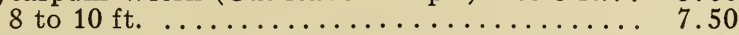

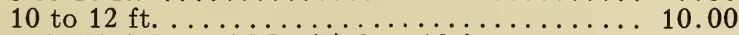

"Negundo (Ash-leaved Maple) 8 to $10 \mathrm{ft}$......... 4.00

10 to $12 \mathrm{ft}$. heavy ................ 7.50

"platanoides (Norway Maple) 6 to $8 \mathrm{ft} \ldots \ldots \ldots \ldots .55$

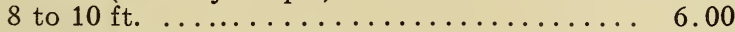

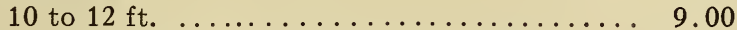

Per 100

$\$ 30.00$

65.00

45.00

65.00

35.00

60.00

40.00

50.00

" plat. var. Schwedleri (Purple-leaved Norway)

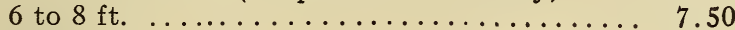

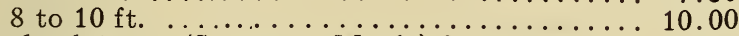

"Pseudo platanus (Sycamore Maple) 8 to $10 \mathrm{ft}$..... 9.00

“Pseudo platanus purpurea (Purple-leaved Sycamore)

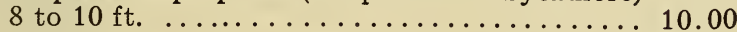

" rubrum (Scarlet or Red Maple) 10 to $12 \mathrm{ft}$........ 15.00

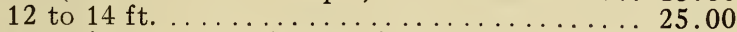

" sacharum (Sugar or Rock Maple) 8 to $10 \mathrm{ft}$. ..... 6.00

10 to $12 \mathrm{ft}, 1 \mathrm{r} / 4$ to $1 \mathrm{I} / 2 \mathrm{in}$. caliper .......... 9.00

12 to $14 \mathrm{ft.,} 13 / 4$ to 2 in. caliper ............ 13.50

" spicatum (Mountain Maple) 4 to $5 \mathrm{ft}$............. 7.50

“Tataricum Ginnala (Siberian Maple) 3 to $4 \mathrm{ft}$. . . . . 1.50

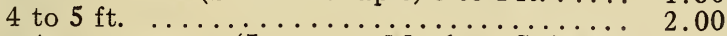

80.00

Acer palmatum aureum (Japanese Maples, Golden-

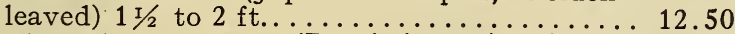

palmatum atropurpureum (Purple-leaved) $21 / 2$ to $3 \mathrm{ft} 12.50$

palmatum dissectum atropurpureum, 18 to 24 in... 15.00

Aesculus Hippocastanum (European Horse-Chestnut)

6 to $8 \mathrm{ft}$............................ 6.00

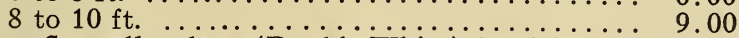

Hippo. flora alba plena (Double White) 6 to $8 \mathrm{ft} \ldots \ldots 9.00$

55.00

85.00

125.00

12.00

15.00

Hippo. rubicunda (Double Red) 6 to $8 \mathrm{ft}$. ......... 10.00 Ailanthus gland ulosa (Tree of Heaven) 6 to $8 \mathrm{ft} . \ldots \ldots \ldots . . .60$ 
Per 10

Per 100

Alnus incana (Alder) $3 \mathrm{ft} . \ldots \ldots \ldots \ldots \ldots \ldots \ldots \ldots \ldots$

$\$ 15.00$

Aralia spinosa (Angelica Tree) 3 to $4 \mathrm{ft}$. $3 \ldots \ldots \ldots \ldots$
Betula alba (European White Birch) 4 to $5 \mathrm{ft} . \ldots \ldots \ldots$
3.50

6 to $8 \mathrm{ft} . \ldots \ldots \ldots \ldots \ldots \ldots \ldots \ldots . \ldots \ldots$

30.00

" alba laciniata pendula (Cut-leaved WeepingBirch)

5 to $6 \mathrm{ft} . \ldots \ldots \ldots \ldots \ldots \ldots \ldots \ldots \ldots \ldots \ldots \ldots$ 6 to $8 \mathrm{ft}$.

6.00

7.50

50.00

" lenta (Sweet Birch) 4 to $5 \mathrm{ft} \ldots \ldots \ldots \ldots \ldots \ldots$

4.00

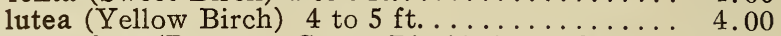

papyrifera (Paper or Canoe Birch) 5 to $6 \mathrm{ft}$. ... 4.00

populifolia (Gray Birch) 5 to $6 \mathrm{ft} \ldots \ldots \ldots \ldots . \ldots 3.00$

Carpinus Americana (Hornbeam) 2 to $3 \mathrm{ft} . \ldots \ldots \ldots . . . . .300$

60.00

35.00

25.00

25.00

Castanea (Chestnut)

Americana (Am. Chestnut) 4 to $5 \mathrm{ft} . \ldots \ldots \ldots \ldots .600$

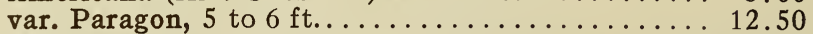

40.00

Japonica (Japan Chestnut) 4 to $5 \mathrm{ft} . \ldots \ldots \ldots \ldots \ldots$

Vesca (Spanish Chestnut) 4 to $5 \mathrm{ft} . \ldots \ldots \ldots \ldots \ldots$

Catalpa Bungei, standards, 6 to $8 \mathrm{ft}$. 2 yr. heads.......

speciosa (Western Catalpa) 8 to $10 \mathrm{ft}$. ...........

Celtis occidentalis (Nettle Tree) $5 \mathrm{ft} . \ldots \ldots \ldots \ldots \ldots$.

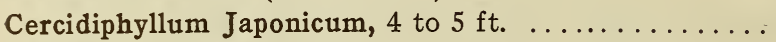

6.00

50.00

Cercis Canadensis( Red Bud) 3 to $4 \mathrm{ft}$........... 5.00

Cerasus Japonica rosea pendula (Weeping Cherry) 2 yr. heads......................... 12.50

" Japonica flore plena, 4 to $5 \mathrm{ft} \ldots \ldots \ldots \ldots \ldots \ldots . \ldots \ldots 7.50$

“ padus (Bird Cherry) $3 \mathrm{ft} \ldots \ldots \ldots \ldots \ldots \ldots \ldots .2 .50$

Chionanthus (See Deciduous Shrubs).

20.00

Cladrastis tinctoria (Yellow Wood) 5 to $6 \mathrm{ft}$........ 10.00

Cornus florida (White-flowering Dogwood) trans.

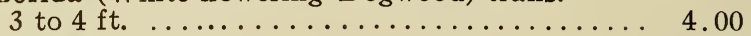

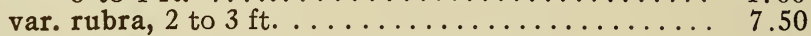

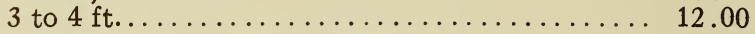

Crataegus coccinea (American White Thorn)

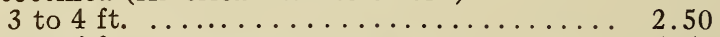

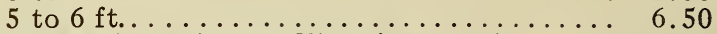

" cordata (Washington Thorn) 3 to $4 \mathrm{ft} . . . . .30$

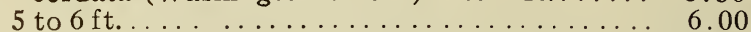
crus-galli (Cockspur Thorn) 3 to $4 \mathrm{ft}$..... 3.50

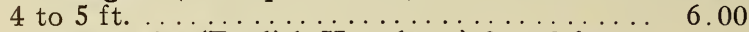
oxyacantha (English Hawthorn) 2 to $3 \mathrm{ft}$... 1.50 oxyacantha alba plena (Double White Thorn)

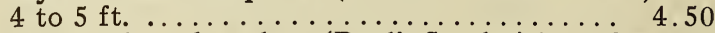
oxyacantha rubra plena (Paul's Scarlet) 4 to $5 \mathrm{ft}$. 4.50

Cytisus (See Laburnum)
Fagus ferruginea (American Beech) 4 to $5 \mathrm{ft}$.

40.00

sylvatica (European Beech) 3 to $4 \mathrm{ft}$........... 5.00

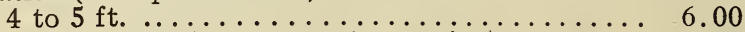

var. heterophylla (Fern-leaved Beech) 2 to $3 \mathrm{ft}$.... 10.00

var. purpurea (Copper Beech) 4 to $5 \mathrm{ft}$........ 6.00

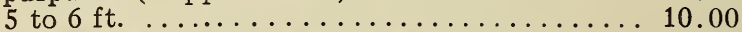

var. Riversii (River's Purple Beech) 4 to $5 \mathrm{ft}$. ..... 10.00

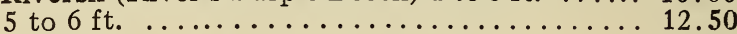

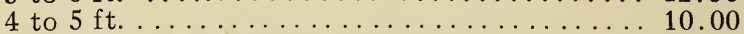

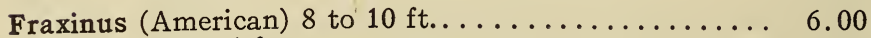

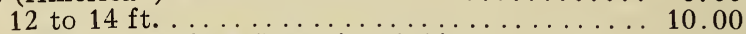

90.00

“ exelsior pendula (Weeping Ash) 2 yr. heads .. 12.50 
Ginkgo biloba (Salisburia or Maiden-hair Tree)

Gleditschia triacanthos (Honey Locust) 10 to 12 in...... 1.00

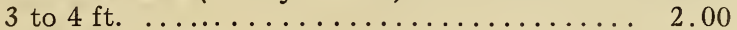

Gymnocladus Canadensis (Kentucky Coffee Tree)

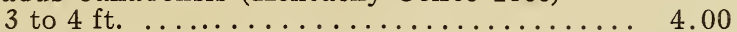

Juglans cinerea (Butternut) 5 to $6 \mathrm{ft}$............... 4.50 nigra (Black Walnut) 4 to $5 \mathrm{ft}$. ........... 4.50 " regia (English Walnut) 4 to $6 \mathrm{ft}$. . . . . . . . . 7.50

Koelreuteria paniculata (Varnish Tree) $6 \mathrm{ft} . \ldots \ldots \ldots \ldots . . \ldots 7.50$

Laburnum vulgare (Golden Chain) $5 \mathrm{ft} . \ldots \ldots \ldots \ldots \ldots . . . .50$

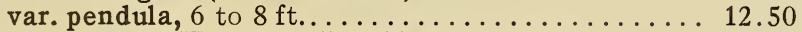

Larix Europaeus (European Larch) 4 to $5 \mathrm{ft}$......... 3.50

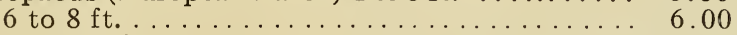

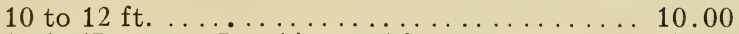

leptolepis (Japanese Larch) 4 to $5 \mathrm{ft} . \ldots \ldots \ldots \ldots \ldots 7.50$

Liquidambar styraciflua (Sweet Gum) 8 to $10 \mathrm{ft} . \ldots \ldots . . .12 .50$

Liriodendron tulipifera (Tulip Tree) 6 to $8 \mathrm{ft} . \ldots \ldots \ldots 7.50$

Magnolia acuminata (Cucumber Tree) 6 to $8 \mathrm{ft} . \ldots \ldots .7 .50$

Alexandrina, 4 to $5 \mathrm{ft}$, with ball. . . . . 15.00

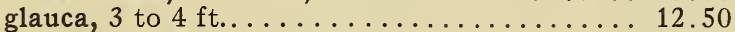

Lennei, 4 to $5 \mathrm{ft}$., with ball............ 12.50

Soulangeana, 4 to $5 \mathrm{ft}$, with ball .......... 12.50

Speciosa, 4 to $5 \mathrm{ft}$., with ball........... 12.50

Stellata, (Halleana) $2 \mathrm{ft}$, with ball. ....... 15.00

Morus alba Tatarica (Russian Mulberry) 3 to $i \mathrm{ft}$....... 2.00

"“ " (Russian Mulberry) 6 to $7 \mathrm{ft}$...... 4.00

alba pendula (Weeping Mulberry) ............ 10.00

New American or Downing, 5 to $6 \mathrm{ft}$. grafted..... 6.00

Ostrya Virginica (Ironwood) $2 \mathrm{ft}$............... 3.50

Paulownia Imperialis (Empress Tree) 6 to $8 \mathrm{ft}$. . . . . each 1.00

Pavia mecrostachya, (Dwarf Buckeye) $11 / 2$ to $2 \mathrm{ft}$.... 4.00

Persica var. purpurea (Blood-leaved Peach) 3 to $4 \mathrm{ft}$..... 2.50

alba plena (Double white-flowered Peach) 3 to $4 \mathrm{ft}$. 2.50

rosea plena (Double pink-flowered Peach) 3 to $4 \mathrm{ft} . \quad 2.50$

Platanus orientalis (Oriental Plane) 8 to $10 \mathrm{ft}$........ 10.00 occidentalis, 8 to $10 \mathrm{ft}$. .................. 10.00

Populus alba (White or Silver Poplar) 6 to $7 \mathrm{ft} . \ldots \ldots \ldots . . .5 .00$

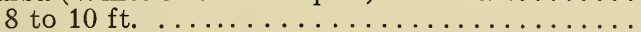

"Bolleana, 8 to $10 \mathrm{ft} . \ldots \ldots \ldots \ldots \ldots \ldots \ldots \ldots \ldots \ldots \ldots$ 10 to $12 \mathrm{ft} . \ldots \ldots \ldots \ldots \ldots \ldots \ldots \ldots \ldots \ldots \ldots \ldots$

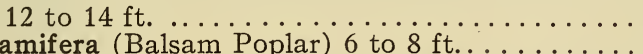

“ balsamifera (Balsam Poplar) 6 to $8 \mathrm{ft} . \ldots \ldots \ldots \ldots$.

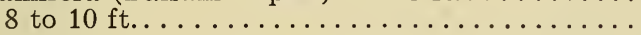
$10 \mathrm{ft} 12 \mathrm{ft} . \ldots \ldots \ldots \ldots \ldots \ldots \ldots \ldots \ldots$

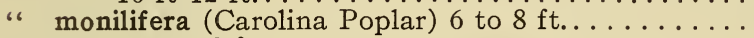
10 to $12 \mathrm{ft} . \ldots \ldots \ldots \ldots \ldots \ldots \ldots$ 12 to $14 \mathrm{ft} . \ldots \ldots \ldots \ldots \ldots \ldots \ldots$

" nigra fastigiata (Lombardy Poplar) 6 to $8 \mathrm{ft}$........ 8 to $10 \mathrm{ft} . \ldots \ldots \ldots \ldots \ldots \ldots \ldots \ldots \ldots$ 10 to $12 \mathrm{ft} . \ldots \ldots \ldots \ldots \ldots \ldots \ldots \ldots$ 12 to $14 \mathrm{ft} . \ldots \ldots \ldots \ldots \ldots \ldots \ldots \ldots \ldots$

" tremuloides (Aspen Poplar) 6 to $8 \mathrm{ft}$...........

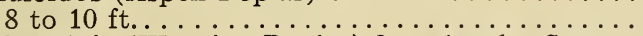
var. Pendula (Weeping Poplar) 2 yr. heads. Strong.

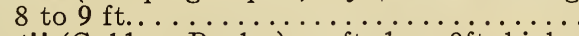

5.00

6.00

7.50

10.00

4.00

5.00

6.00

2.00

4.50

6.00

1.50

4.00

5.00

9.00

30.00

40.00

3.00

4.50

35.00

30.00

50.00

35.00

40.00

10.00

40.00

50.00

10.00

35.00

40.00

25.00

$7.00 \quad 50.00$

Van Geertiu (Golden Poplar) grafted on $8 \mathrm{ft}$. high stems. 


\section{ORNAMENTAL TREES-(Continued)}

Per 100

Prunus Pissardi (Purple-leaved Plum) 4 to $5 \mathrm{ft} . \ldots \ldots \$ 3.50$ tribola (Double flowering Plum) 2 to $3 \mathrm{ft} . \ldots \ldots \ldots 2.00$

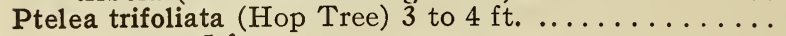
4 to $5 \mathrm{ft} . \ldots \ldots \ldots \ldots \ldots \ldots \ldots \ldots \ldots \ldots \ldots \ldots$

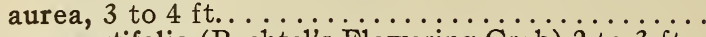

Pyrus angustifolia (Bechtel's Flowering Crab) 2 to $3 \mathrm{ft}$. Atrosanguinea, 3 to $4 \mathrm{ft} . \ldots \ldots \ldots \ldots \ldots \ldots$ Parkmanii, 2 to $3 \mathrm{ft} . \ldots \ldots \ldots \ldots \ldots \ldots \ldots$ Scheideckeri, 2 to $3 \mathrm{ft} . \ldots \ldots \ldots \ldots \ldots \ldots \ldots \ldots \ldots$ Pyrus Sorbus (Mountain Ash)

Americana (American Mountain Ash) 3 to $4 \mathrm{ft} . . . .$. Aucuparia, 5 to $6 \mathrm{ft} . \ldots \ldots \ldots \ldots \ldots \ldots \ldots \ldots$

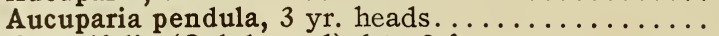
Quercifolia (Oak-leaved) 6 to $8 \mathrm{ft} . \ldots \ldots \ldots \ldots \ldots$. Quercus alba (White Oak) 5 to $6 \mathrm{ft} . \ldots \ldots \ldots \ldots \ldots \ldots$ " " " $7 \mathrm{ft} . \ldots \ldots \ldots \ldots \ldots \ldots \ldots$ coccinea (Scarlet Oak) 6 to $8 \mathrm{ft} . \ldots \ldots \ldots \ldots$. macrocarpa (Mossy Cup Oak) $6 \mathrm{ft} . . . \ldots \ldots \ldots$ palustris (Pin Oak) 8 to $10 \mathrm{ft} . \ldots \ldots \ldots \ldots \ldots$ rubra (Red Oak) 8 to $10 \mathrm{ft} . \ldots \ldots \ldots \ldots \ldots \ldots$

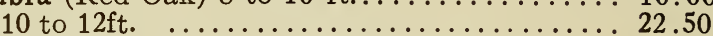

Robinia Pseudacacia (Black Locust) 5 to $6 \mathrm{ft} \ldots \ldots \ldots \ldots 2.50$ 1.00

2.50

3.00

3.00

3.00

2.50

$\$ 18.00$ 6.00 7.00

4.50

4.00

7.50

4.50

5.00

10.00

10.00

12.25

12.50

10.00

Salisburia (See Ginkgo)

Salix alba (White Willow) 4 to $5 \mathrm{ft}$. ........... 1.20

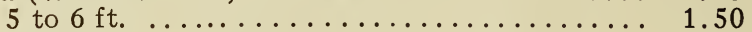

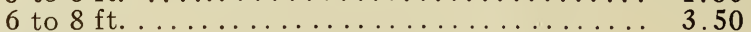

8 to $10 \mathrm{ft} . . \ldots \ldots \ldots \ldots \ldots \ldots \ldots \ldots$

" cuprea pendula (Kilmarnock Weeping Willow).....

" regalis (Royal Willow) 4 to $5 \mathrm{ft}$. ............. 5 to $7 \mathrm{ft}$.

5.00

7.50

3.50

5.00

" rosemarinifolia (Half Standards) 5 to $6 \mathrm{ft} \ldots \ldots \ldots \ldots 10.00$

“pentandra or laurifolia (Laurel or Glass Willow) 18 to 24 in., per M. $\$ 60.00 \ldots \ldots \ldots \ldots \ldots$.

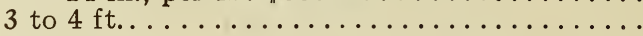

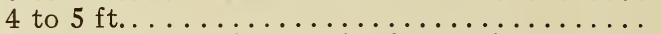

"pentandra (In Pyramid Form) $3 \mathrm{ft}$. 18 in.

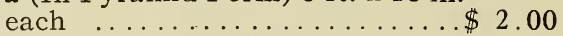

pentandra (In Giobe Form) 2 by 2 ft., each 2.00

pentandra (Clipped Square) $2 \times 2 \mathrm{ft}$. each. 2.00

"vitellina aurea (Golden-barked Willow) 4 to $5 \mathrm{ft}$.....

5 to $6 \mathrm{ft} . \ldots \ldots \ldots \ldots \ldots \ldots \ldots \ldots$

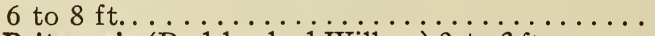

" var. Britzensis (Red-barked Willow) 2 to $3 \mathrm{ft} . . . \ldots$. .

Wisconsin Weeping, 4 to $5 \mathrm{ft} . \ldots \ldots \ldots \ldots \ldots$.

Sassafras officinalis, 4 to $5 \mathrm{ft} \ldots \ldots \ldots \ldots \ldots$

Syringa Japonica (Japanese Tree Lilac) 4 to $5 \mathrm{ft}$...... 4.00

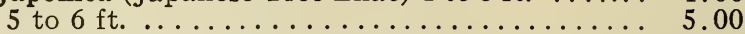

.80
1.20

7.00

1.50

30.00

90.00

8.00

10.00

30.00

40.00

1.20

8.00

1.50

10.00

$4.00 \quad 30.00$

$1.00 \quad 8.00$

2.50

8.00

10.00

Taxodium distichum (Southern Cypress) 3 to $4 \mathrm{ft} . \ldots . .4 \quad 4.00$

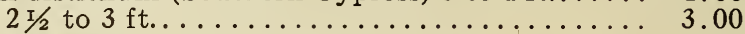

30.00

40.00

20.00

Tilia Americana (American Linden) 6 to $8 \mathrm{ft}$. ......... 8 to $10 \mathrm{ft}$.

5.00

7.50

45.00

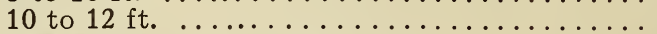

Europaeus (European Linden) 6 to $8 \mathrm{ft} . \ldots \ldots \ldots \ldots$

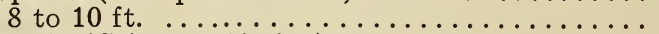

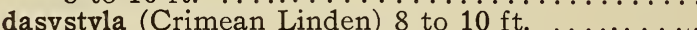

platyphyllos (Large-leaved Linden) 8 to $10 \mathrm{ft} . \ldots \ldots$. .

9.00

4.50

7.50

60.00

40.00

60.00

70.00

$7.50 \quad 70.00$ 


\section{ORNAMENTAL TREES-(Continued)}

Ulmus Americana (American Elm) 7 to $8 \mathrm{ft}$

Per 100

8 to $10 \mathrm{ft}$

$\$ 30.00$

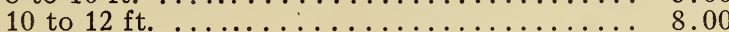

40.00

Specimens, 3 to 4 in. caliper, $\$ 3.00$ to $\$ 5.00$

75.00 each.

campestris (English Elm) 9 to $10 \mathrm{ft}$. .......... 10.00

Camperdowni Pendula (Camperdown Weeping Elm) each, $\$ 1.50$

\section{Evergreens}

All our Evergreens have been frequently transplanted and have an abundance of fibrous roots.

We have a number of Extra Large Specimens, not listed here, and will furnish list of such, and price upon application.

Roots burlapped at an additional expense of 5 cents each for trees up to 3 feet. All over this size 10 cents each.

\begin{tabular}{|c|c|c|c|}
\hline & Each & Per 10 & Per 100 \\
\hline Abies balsamea (Balsam Fir) 2 to $3 \mathrm{ft.....}$ & $\$ 0.35$ & $\$ 3.00$ & $\$ 20.00$ \\
\hline 3 to $4 \mathrm{ft} . \ldots \ldots \ldots \ldots \ldots \ldots$ & .50 & 3.50 & 25.00 \\
\hline 4 to $5 \mathrm{ft}$. & .60 & 4.50 & 35.00 \\
\hline 5 to $6 \mathrm{ft}$. & .75 & 6.00 & 45.00 \\
\hline 6 to $7 \mathrm{ft}$.. & 1.25 & 10.00 & \\
\hline
\end{tabular}

Canadensis (Hemlock). See Tsuga Canadensis

Concolor (Blue Fir) $2 \mathrm{ft} . \ldots \ldots \ldots \ldots \ldots$

3 to $4 \mathrm{ft.} \ldots \ldots \ldots \ldots \ldots \ldots \ldots \ldots \ldots \ldots \ldots \ldots$

4 to $5 \mathrm{ft} . \ldots \ldots \ldots \ldots \ldots \ldots \ldots \ldots$.

5 to $6 \mathrm{ft} . \ldots \ldots \ldots \ldots \ldots \ldots \ldots \ldots \ldots$

6 to $7 \mathrm{ft} . \ldots \ldots \ldots \ldots \ldots \ldots \ldots$

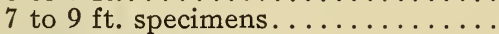

Hudsonica glauca, $2 \mathrm{ft} . \ldots \ldots \ldots \ldots \ldots \ldots$

Nordmanniana (Nordmann's Fir) 3 to $4 \mathrm{ft}$

Veitchii (Veitch's Silver Fir) 2 to $2 \mathrm{r} / 2 \mathrm{ft}$. . .

$21 / 2$ to $3 \mathrm{ft} . \ldots \ldots \ldots \ldots \ldots \ldots \ldots$

3 to $31 / 2 \mathrm{ft} . \ldots \ldots \ldots \ldots \ldots \ldots \ldots$

5 to $6 \mathrm{ft}$. specimens ................. 2.50

$1.75 \quad 15.00$

$3.00 \quad 25.00$

$3.50 \quad 30.00$

$5.00 \quad 45.00$

$6.00 \quad 50.00$

$\begin{array}{ll}7.00 & 60.00\end{array}$

1.75

$2.50 \quad 20.00$

$1.25 \quad 10.00$

$1.50 \quad 12.50$

2.00

$2.50 \quad 20.00$

Biota orientalis (Chinese Arborvitae $2 \mathrm{t} / 2$ to $3 \mathrm{ft}$. 1.00

" nana aurea (Golden Chinese Arborvitae)

18 to 24 in. ..................

24 to 30 in. $\ldots \ldots \ldots \ldots \ldots \ldots \ldots \ldots \ldots \ldots$

3 to $4 \mathrm{ft}$.

$1.25 \quad 10.00$

$1.60 \quad 15.00$

3. $50 \quad 30.00$

Cedrus Atlantica glauca (Silvery Cedar) $2 \frac{1}{2}$ to

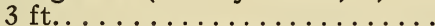

Cupressus var. Triumph of Boskoop (Pyrami-

$1.50 \quad 12.50$ dal Silvery Cypress) 4 to $5 \mathrm{ft} . .3 .00$

Chamaecyparis. (See Retinispora)

Juniperus communis prostrata (Dwarf Spreading Juniper) 12 to 15 in........

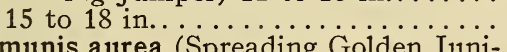
communis aurea (Spreading Golden Juni-

Chinensis, 2 ft. . . . . . . . . . . . . .

Chinensis var. argentea (White-tipped Juniper) 1 to $1 \mathrm{r} / 2 \mathrm{ft} . \ldots \ldots \ldots \ldots$

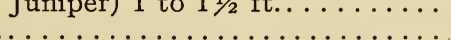


EVERGREENS-(Continued)

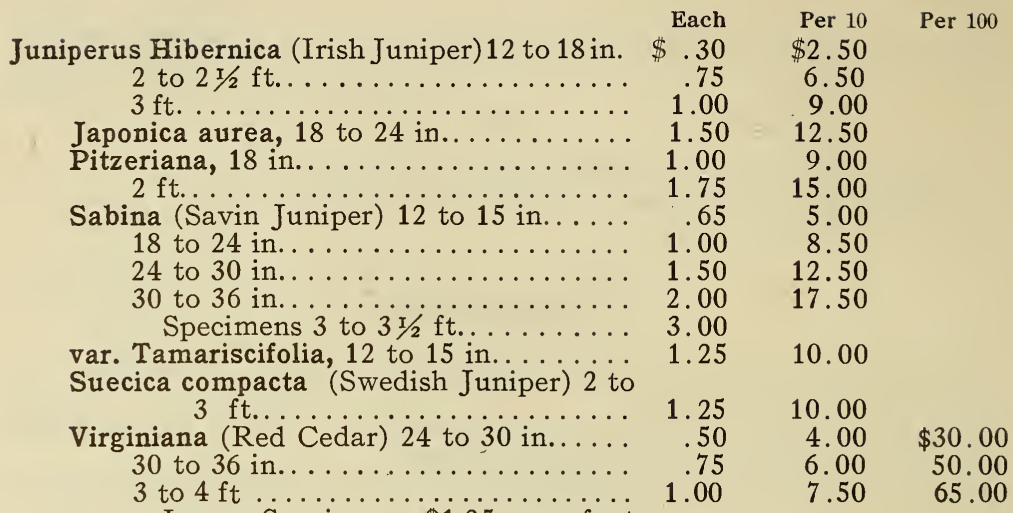

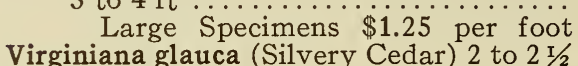

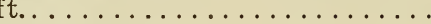
$4 \mathrm{ft} \ldots \ldots \ldots \ldots \ldots \ldots \ldots \ldots \ldots \ldots$

var. Schottii, 2 to $2 \mathrm{i} / 2 \mathrm{ft} \ldots \ldots \ldots \ldots \ldots \ldots . . . .50$

Picea alba (White Spruce) $21 / 2$ to $3 \mathrm{ft} . \ldots \ldots . .40$ 3 to $4 \mathrm{ft} . . \ldots \ldots \ldots \ldots \ldots \ldots$.

4 to $5 \mathrm{ft} . \ldots \ldots \ldots \ldots \ldots \ldots$

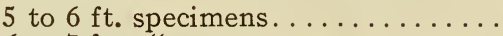
6 to $7 \mathrm{ft}$.

.60

1.00

1.75

2.00

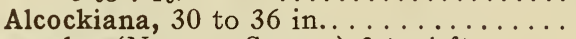
excelsa (Norway Spruce) 3 to $4 \mathrm{ft}$...... 4 to $5 \mathrm{ft} . \ldots \ldots \ldots \ldots \ldots \ldots$

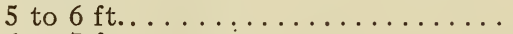

6 to $7 \mathrm{ft} . \ldots \ldots \ldots \ldots \ldots \ldots$

7 to $9 \mathrm{ft} . \ldots \ldots \ldots \ldots \ldots . \ldots . \ldots . \ldots$

excelsa var. aurea (Golden Spruce) 4 to $5 \mathrm{ft} . \ldots \ldots \ldots \ldots \ldots \ldots \ldots$

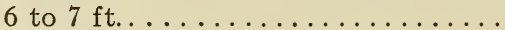
excelsa var. conica, $1 \mathrm{r} / 2 \mathrm{ft} . \ldots \ldots \ldots \ldots$ excelsa var. Gregoriana (Gregory's Spruce)

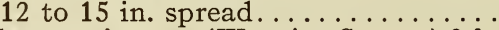
excelsa var. inverta (Weeping Spruce) $2 \mathrm{ft}$.

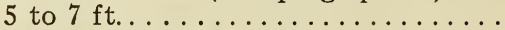
excelsa var. pumila (Dwarf Spruce) 12

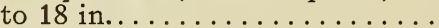

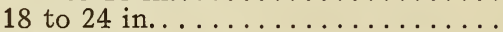
orientalis (Oriental Spruce) 2 to $3 \mathrm{ft} . .$. polita (Tiger tail Spruce) $2 \mathrm{ft} . . . . . . . .$. pungens (Colorado Spruce) 24 to $30 \mathrm{in...}$

3 to $4 \mathrm{ft} . . \ldots \ldots \ldots \ldots \ldots \ldots . . . \ldots$

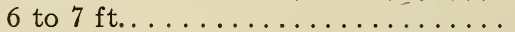

7 to $9 \mathrm{ft} . \ldots \ldots \ldots \ldots \ldots \ldots \ldots \ldots$ pungens var. glauca (Colorado Blue Spruce) 2 to $3 \mathrm{ft} . \ldots \ldots \ldots \ldots \ldots 1.25$ 
EVERGREENS-(Continued)

Each

Pinus Austriaca (Austrian Pine) $2 \mathrm{r} / 2$ to $3 \mathrm{ft} . \$ 1.00$ $\$ 9.00$

Pinus Banksiana or divaricata (Jack Pine) 3 to $4 \mathrm{ft} . \ldots \ldots \ldots \ldots \ldots \ldots$

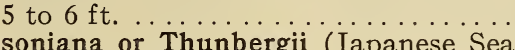

"Massoniana or Thunbergii (Japanese Sea Shore Pine) $3 \mathrm{ft} . . . \ldots \ldots \ldots \ldots$

Mughus (Dwarf Mointain Pine) 15 in.... 18 in.

$4.00 \$ 30.00$

" Montana (Upright Mountain Pine) 15 to 18 in.

1.00

9.00

80.00

24 to $30 \mathrm{in}$.

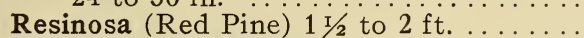

strobus (White Pine) 18 to 24 in. ........ 24 to 30 in.

3 to $4 \mathrm{ft}$.

$\ldots \ldots \ldots \ldots \ldots \ldots \ldots \ldots$

8.00

5 to $6 \mathrm{ft}$

1. 50

$\ldots \ldots \ldots \ldots \ldots \ldots \ldots \ldots \ldots$

sylvestris (Scotch Pine) $2 \mathrm{ft} \ldots \ldots \ldots \ldots \ldots . .40$

3 to $4 \mathrm{ft} . \ldots \ldots \ldots \ldots \ldots \ldots \ldots \ldots . .75$

Pseudotsuga Douglasii (Douglas' Spruce) 2 to $2 \mathrm{t} / 2 \mathrm{ft} . \ldots \ldots \ldots \ldots \ldots \ldots \ldots$

$3 \mathrm{t} / 2$ to $4 \mathrm{ft} . \ldots \ldots \ldots \ldots \ldots \ldots \ldots \ldots \ldots \ldots \ldots$

$.60 \quad 5.00$

$1.25 \quad 10.00$

Retinispora filifera (Thread-branched Japan

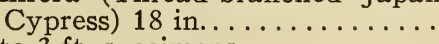

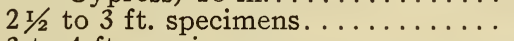

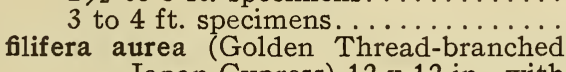
Japan Cypress) 12 x 12 in., with obtusa (Obtuse-leaved Japan Cypress)

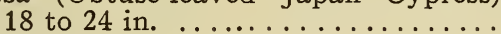

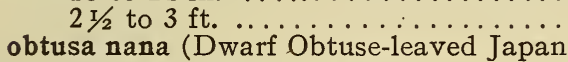
Cypress) 10 to 12 in.......... obtusa gracilis, 2 to $2 \mathrm{r} / 2 \mathrm{ft} . \ldots . . . . . . . .$.
pisifera (Pea-fruited Japan Cypress) 2 to $2 \mathrm{t} / 2 \mathrm{ft} \ldots \ldots \ldots \ldots \ldots \ldots \ldots$

3 to $4 \mathrm{ft} . \ldots \ldots \ldots \ldots \ldots \ldots \ldots \ldots \ldots$

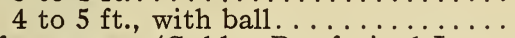
pisifera aurea (Golden, Pea-fruited Japan Cypress) 2 to $21 / 2 \mathrm{ft} . \ldots \ldots \ldots$.

3 to $4 \mathrm{ft}$., with ball. .............. plumosa (Plume-like Japan Cypress) 2 to $3 \mathrm{ft}$.

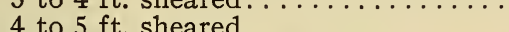

" plumosa aurea (Golden Plume-like Japan Cypress) 18 to 24 in. ..........

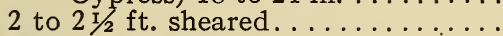

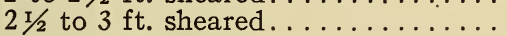

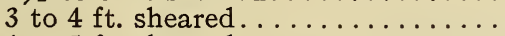

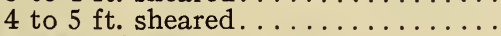
squarrosa, $3 \mathrm{ft}$.

4.00

17.50

35.00

$\begin{array}{rr}.75 & 6.00 \\ 1.25 & 10.00\end{array}$

1.25

10.00

2.00

17.50

2.75

25.00

4.00

37.50

Sciadopitys verticillata (Ümbrella Pine)

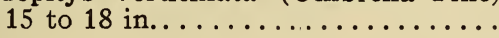




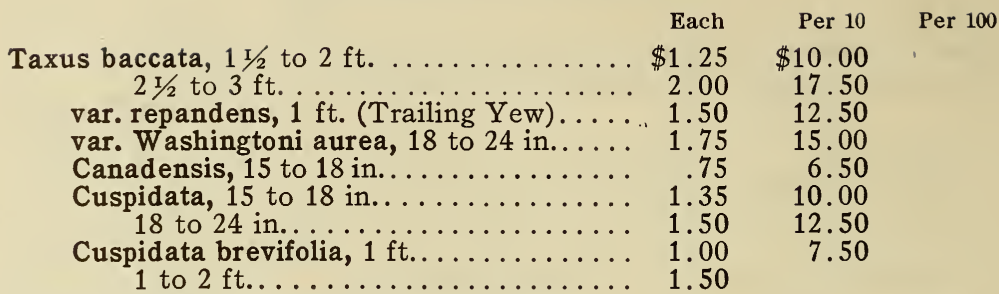

Thuya occidentalis (American Arborvitae)

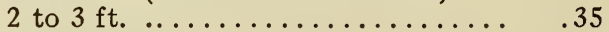

3.00

$\$ 20.00$

3 to $4 \mathrm{ft} . \ldots \ldots \ldots \ldots \ldots \ldots \ldots \ldots \ldots \ldots \ldots$

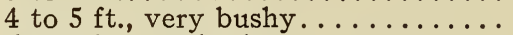

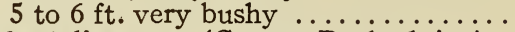
occidentalis aurea (George Peabody's Arborvitae) 3 to $31 / 2 \mathrm{ft} . \ldots \ldots \ldots$

$4 \mathrm{ft}$. specimens................

4.00

35.00

$\begin{array}{lll}1.00 & 9.00 \quad 80.00\end{array}$

1. $50 \quad 12.25$

$1.25 \quad 10.00$

occidentalis globosa (Globe Arborvitae)

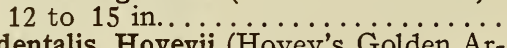

1.75

$.50 \quad 4.00$

occidentalis Hoveyii (Hovey's Golden Ar-

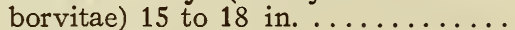

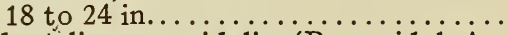

occidentalis pyramidalis (Pyramidal Arborvitae) 3 to $4 \mathrm{ft} . . \ldots \ldots \ldots$.

4 to $5 \mathrm{ft}$...........................

occidentalis Sibirica (Siberian Arborvitae)
2 to $21 / 2 \mathrm{ft} . \ldots \ldots \ldots \ldots \ldots \ldots \ldots \ldots$

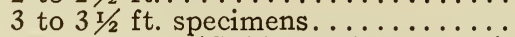

var. Vervaeneana (Golden and green variegated Arborvitae) $2 \mathrm{ft} . . . \ldots \ldots$

occidentalis Tom Thumb (Dwarf Arborvitae) 18 to 24 in., with ball....

Tsuga Canadensis (Canadian Hemlock) 10 to

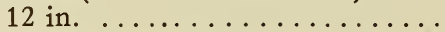

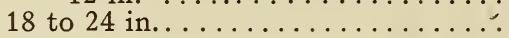

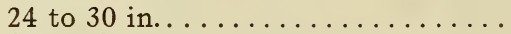

3 to $4 \mathrm{ft} . \ldots \ldots \ldots \ldots \ldots \ldots \ldots$

4 to $5 \mathrm{ft} . \ldots \ldots \ldots \ldots \ldots \ldots \ldots \ldots \ldots$

5 to $6 \mathrm{ft} . \ldots \ldots \ldots \ldots \ldots \ldots \ldots \ldots \ldots$

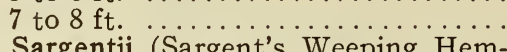

var. Sargentii (Sargent's Weeping Hem-

$.40 \quad 3.50$

$.75 \quad 6.00$

50.00

$.90 \quad 7.50$

$1.00 \quad 9.00$

$.75 \quad 6.50$

$1.50 \quad 12.00$

$.50 \quad 4.50$

$.75 \quad 6.50$

3.50

5.00

30.00

.75

6.50

1.50

12.50

$2.00 \quad 17.50$

3.75

35.00

$5.00 \quad 45.00$

40.00

60.00

1.75

\section{Evergreen Shrubs}

Andromeda Catesbaei (Leucothoe Catesbaei) 12 to 15 in.............. 0.50

floribunda, 10 to $12 \mathrm{in} . \ldots \ldots \ldots \ldots \ldots \ldots . .75$

15 to 18 in...................... 1.25

Arctostaphyllos uva ursi (Bearberry) ....... $\quad .25$

Per 10 Per 100

$\$ 4.00$

7.00

10.00

Azalea amoena (Lovely Azalea) 10 to 12 in., bushy................. 1.00

$2.00 \$ 15.00$

" Jap. var. Hinodegeri

$1.00 \quad 9.00$

(Dark red) 8 to 12 in. 


\section{EVERGREEN SHRUBS-(Continued)}

Berberis aquifolia or Mahonia (Ashberry) 18 to 24 in., bushy...........\$.35

Buxus sempervirens, 12 to 15 in., bush form .. .35

15 t'o 18 in., bush form ........... .60

18 to 24 in., bush form ............ 1.25

$21 / 2 \mathrm{ft}$., bush form (specimen plants).. 2.00 specimens ................

$3 \mathrm{ft}$. sheared specimens .......... 2.50

$31 / 2 \mathrm{ft}$. sheared specimens ........ 3.00

$4 \mathrm{ft}$. sheared specimens .............

$41 / 2 \mathrm{ft}$. sheared specimens ............

$5 \mathrm{ft}$. sheared specimens ........... sempervirens . Standards

18 in. crown, $1 \frac{1}{2} \mathrm{ft}$. stem (Baby Standards) ...............

18 in. crown, $21 / 2$ to $3 \mathrm{ft}$. stem ....... sempervirens nana (Dwarf Box, for edging) 4 to 6 in. ..............

1.50

2.50 sempervirens pyramids, $21 / 2 \mathrm{ft}$., sheared

\section{Bay Trees}

Standard, 26 in. crown, 32 in. stem ......... \$7.00

Pyramid, $5 \mathrm{r} / 2 \mathrm{ft}$. high $\ldots \ldots \ldots \ldots \ldots \ldots \ldots \ldots \ldots \ldots 12.00 \ldots \ldots$

Calluna or Erica (Heather)

vulgaris alba (White) .......... . 25

vulgaris aurea (Golden) ........... $\quad .25$

vulgaris carnea (Pink).............. .25

Chamaedaphne calyculata (Cassandra or Leather Leaf) 18 in.........

Daphne Cneorum (Garland Flower) 4 to 6 in. .

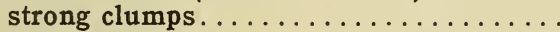

Euonymus radicans (Creeping Euonymus) 2

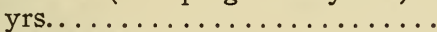

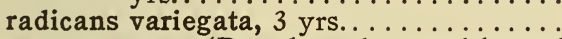

var. vegetus (Broad and round-leaved form) 3 yrs...............

Hedera Helix (English Ivy) Strong Plants.

Two Years. ..................

Ilex opaca (American Holly) 12 to 18 in. ....

Kalmia latifolia (Mountain Laurel) 15 to 18 in., clumps, with ball........

18 to 24 in., clumps, with ball......

2 to $2 \mathrm{I} / 2 \mathrm{ft}$., clumps, with ball...... Special low prices on collected plants in carload lots.

Leucothoe Catesbaei. (See Andromeda)

Mahonia. (See Berberis aquifolia)
Per 10

$\$ 3.00$

3.00

5.00

12.00

17.50

12.50

20.00

25.00

30.00

35.00

40.00

12.50

22.50

1.00

8.00

Per pair

$\$ 13.00$

18.00

24.00

18.00

22.00

Per 10 , Per 100

Each

Per 100

$\$ 25.00$

25.00

40.00

$.60 \quad 5.00$

$.40 \quad 3.00$

.50

$.15 \quad 1.00$

.15

$1.00 \quad 7.50$

$\begin{array}{lll}.75 & 6.50 \quad 50.00\end{array}$

$\begin{array}{lll}1.00 & 9.00 & 75.00\end{array}$
1. 20

8.00

1.80

15.00

$2.50 \quad 20.00$

$\$ 20.00$

12.50 


\section{Hybrid Rhododendrons}

Prices, for well-budded and well furnished plants.

Each

18 to 24 in..................... $\$ 1.25$

24 to 30 in..................... 1.75

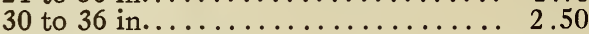

36 to 40 in................... 4.00

Abraham Lincoln (Rosy red)

Album elegeus (White)

Astrosanguinea (Red)

Boule de Neige (White)

Caractacus (Crimson)

Catawbiensis grandiflora (Purple)

Charles Bagley (Bright red)

Charles Dickens (Crimson)

Delicatissimum (Blush white)

Everestianum (Lilac rose)

General Grant (Scarlet)

Giganteum (Red)

H. H. Hunnewell (Crimson)

H. W. Sargent (Crimson)

Lady Armstrong (Pink)

Lady Clermont (Red)

Mrs. Milner (Crimson)

Paron's Gloriosum (Rosy White)

Pres. Lincoln (Rose)

Roseum elegans (Pink)

Rhododendron Catawbiensis

Of this variety we offer strong, native and Nursery-grown plants, well furnished and with large balls, 18 to 24 in.... $\$ 1.00 \quad \$ 9.00$

2 to $2 \mathrm{r} / 2 \mathrm{ft} . \ldots \ldots \ldots \ldots \ldots \ldots \ldots \ldots$

\section{Alpine Varities}

Rhododendron ferrugineum (Pink) 10 to 12 in.

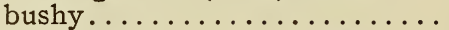

hirsutum (Scarlet) 10 to 12 in., bushy....

Punctatum 18 to 24 in...............

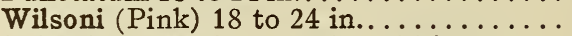

Rhododendron Maximum, 18 to 24 in. ......

2 to $3 \mathrm{ft}$

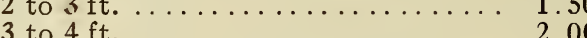

$1.00 \quad 9.00$

$1.00 \quad 9.00$

$1.00 \quad 9.00$

$1.25 \quad 10.00$

$1.00 \quad 9.00$

$1.50 \quad 12.50$

$2.00 \quad 17.50$

Prices on carload lots upon applications.

Yucca filamentosa, 3 yrs.
$\$ 10.00$

22.50
$\$ 75.00$

\section{Deciduous Shrubs}

Acer ginnala (Siberian Bush Maple) 3 to $4 \mathrm{ft} \ldots \ldots \ldots \ldots . \$$ Per 10

Per 100

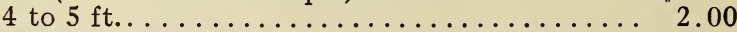

$\$ 12.00$

Almond (See Prunus sinensis)

15.00

Althea (See Hibiscus Syriacus)

Amelanchier botryapium, 2 to $3 \mathrm{ft} . \ldots \ldots \ldots \ldots \ldots \ldots$

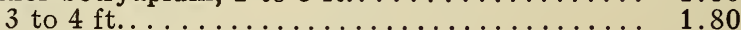

12.00

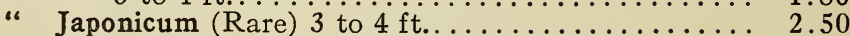

Amorpha canescens (Lead Plant) 12 in............ 1.20

fruticosa (Bastard Indigo) 3 to $4 \mathrm{ft} . \ldots \ldots \ldots \ldots \ldots$ 1.0.

15.00

10.00

Andromeda arborea (Sorrell-Tree) 2 to $3 \mathrm{ft} . \ldots \ldots \ldots .5 .00$ 


\section{DECIDUOUS SHRUBS-(Continued)}

Aralia pentaphylla (Five-leaved Aralia) $2 \mathrm{x} / 2$ to $3 \mathrm{ft} . \ldots \ldots$... $\$ 1.00$

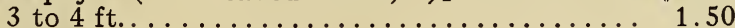

Azalea arborescens, 15 to 18 in. ..................... 6.00

6.00 calendulacea or lutea, 15 to 18 in............ 6.00

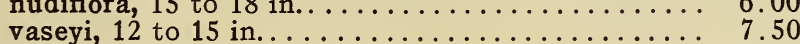

viscosa, 2 to $3 \mathrm{ft} . \ldots \ldots \ldots \ldots \ldots \ldots \ldots \ldots \ldots \ldots . \ldots \ldots$

Ghent, 18 to 24 in...................... 10.00

Azalea mollis, named varieties mixed, 15 to 18 in. ..... 6.00

Unnamed Seedlings, 12 to 18 in. bushy .. 4.00

Per 100

$\$ 8.00$

12.00

50.00

50.00

50.00

Baccharis halimifolia, 2 to $3 \mathrm{ft} . \ldots \ldots \ldots \ldots \ldots \ldots$

Berberis Thunbergii (Japanese Barberry) 12 to 15 in. (per M. $\$ 50.00) \ldots \ldots \ldots \ldots \ldots \ldots \ldots$

15 to 18 in. (per M. $\$ 60.00) \ldots \ldots \ldots \ldots \ldots$

vulgaris (Common Barberry) 18 to 24 in. . ..........

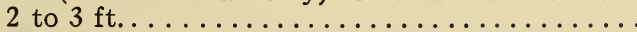

1.20

10.00

12.00

vulgaris purpurea (Purple Barberry) 18 to 24 in.... .

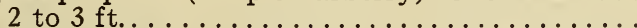

1.00

1. 20

1.00

1. 20

6.00

8.00

10.00

8.00

10.00

7.00

10.00

Calycanthus floridus (Sweet Shrub) 18 to 24 in.......... 1.50

Caragana arborescens (Siberian Pea Tree) 2 to $2 \mathrm{r} / 2 \mathrm{ft} . .$.

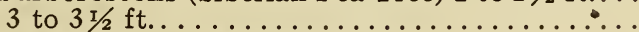

12.00

$1.20 \quad 9.00$

$1.20 \quad 10.00$

Caryopteris Mastacanthus (Blue Spiraea) 2 yrs............... 1.50

Ceanothus Americanus (New Jersey Tea) 2 yrs.......... 1.50

12.00

Cephalanthus occidentalis (Button Bush) $1 \frac{1}{2}$ to $2 \mathrm{ft}$....

Cercis. (See Deciduous Trees).

Chionanthus Virginica (White Fringe) $2 \mathrm{~T} / 2$ to $3 \mathrm{ft}$...... 2.50

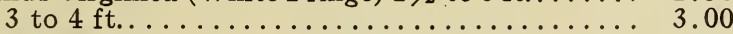

Clethra alnifolia (White Alder) 18 to 24 in................ 1.00

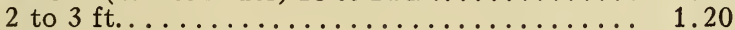

Colutea arborescens (Bladder Senna) $21 / 2$ to $3 \mathrm{ft} . \ldots \ldots . . .61 .50$

Comptonia asplenifolia (Sweet fern) 18 to 24 in.........

Cornus alba, Sibirica (Cornel or Dogwood) 2 to $3 \mathrm{ft}$......

" elegantissima variegata, $2 \mathrm{ft} . . \ldots \ldots \ldots \ldots \ldots$. .

" paniculata (Gray Dogwood) $2 \mathrm{ft} . \ldots \ldots \ldots \ldots \ldots$. . . . . . $3 \mathrm{ft}$.

1.00

1.00

2.50

1.50

2.00

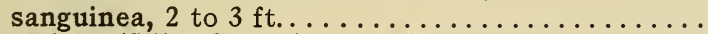

sericea (Silky Cornel) 3 to $4 \mathrm{ft} . \ldots \ldots \ldots \ldots \ldots \ldots$.

1.20

1.00 4 to $5 \mathrm{ft}$.

1. 20

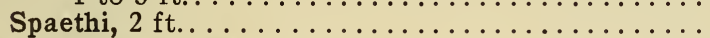

2.50

stolonifera aurea, 18 in............... 2.50

Corylus Americana (Filbert or $\mathrm{Hazel}) 2 \mathrm{ft} . \ldots \ldots \ldots \ldots . \ldots \ldots . .50$

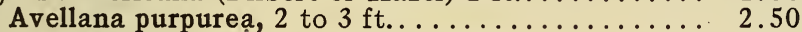

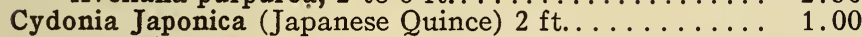

maulei, 12 to 15 in.................... 2.50

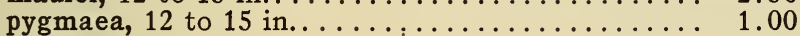

alba, 10 to 12 in............................. 2.50

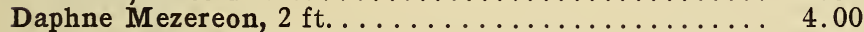

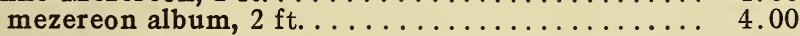

Desmodium (See Lespedeza)

Deutzia crenata flora plena, 3 to $4 \mathrm{ft}$. . . . . . . . 1.50

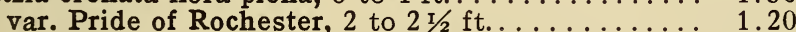

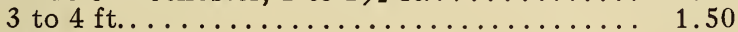

12.00

8.00

10.00

10.00

8.00

8.00

12.00

15.00

8.00

7.00

9.00

12.00

8.00

6.00

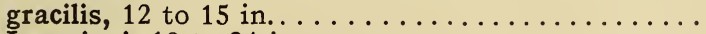

Lemoinei, 18 to 24 in. . . . . . . . . . . . . .

1.50

10.00

12.00

12.00

10.00

2 to $3 \mathrm{ft}$. 
Diervilla candida (Weigelia) 3 to $4 \mathrm{ft} . \ldots \ldots \ldots \ldots \ldots \ldots \$ 2.00$

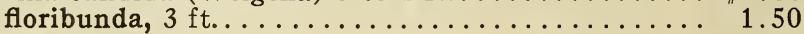

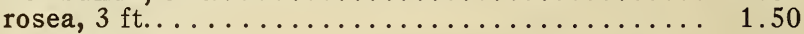

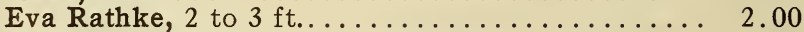

variegata (Variegated-leaved Weigelia) 2 to $21 / 2 \mathrm{ft} . .22 .00$

Eleagnus argentea( Oleaster) 2 to $3 \mathrm{ft} . \ldots \ldots \ldots \ldots \ldots 1.20$

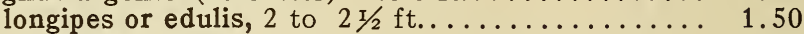

Euonymus alatus (Winged Burning Bush) 18 to 24 in... . 1.50

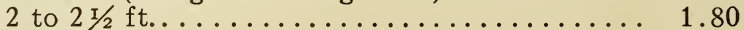

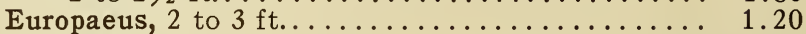

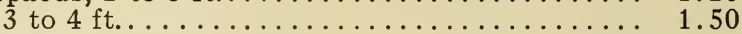

Per 100

$\$ 15.00$

12.00

12.00

15.00

15.00

10.00

12.00

10.00

12.00

10.00

var. latifolia (Long-budded European Euonymus)

Very rare, $3 \mathrm{ft}$. , bushy............. 3.50

12.00

Exochorda grandiflora (Pearl Bush) 2 to $3 \mathrm{ft} . \ldots \ldots \ldots$... 1.50

Forsythia Fortunei (Golden Bell) 2 to $2 \mathrm{I} / 2 \mathrm{ft} \ldots \ldots \ldots \ldots . . . .00$

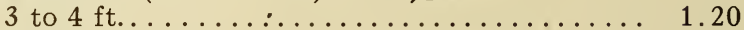

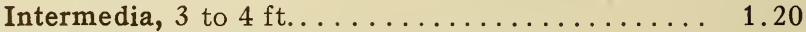

suspensa, (Weeping Golden Bell) 2 to $3 \mathrm{ft} . \ldots \ldots \ldots . . .50$

virdissima, $2 \mathrm{t} / 2$ to $3 \mathrm{ft} . \ldots \ldots \ldots \ldots \ldots \ldots \ldots . \ldots \ldots$

var. aurea (Golden-leaved Forsythia) $3 \mathrm{ft} . \ldots \ldots \ldots 2.50$

25.00

8.00

10.00

10.00

12.00

8.00

10.00

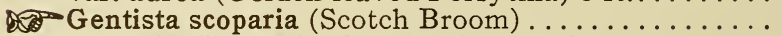

tinctoria (Broom) Strong plants, $2 \mathrm{ft} . \ldots \ldots \ldots \ldots . . . . . .1 .50$

Halesia tetraptera, 3 to $4 \mathrm{ft} . \ldots \ldots \ldots \ldots \ldots \ldots \ldots . \ldots \ldots$

Hamamelis Virginica (Witch Hazel) 18 in. .......... 1.20

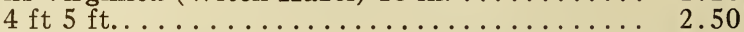

12.00

10.00

Hibiscus Syriacus (Althaea)

alba plena, double white, 2 to $3 \mathrm{ft} . \ldots \ldots \ldots \ldots \ldots 1.50$

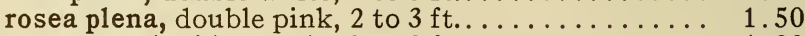

purpurea, double purple, 2 to $3 \mathrm{ft} . \ldots \ldots \ldots \ldots \ldots .1 .20$

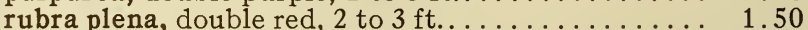

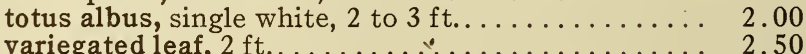

variegated leaf, $2 \mathrm{ft} . \ldots \ldots \ldots \ldots \ldots \ldots \ldots \ldots \ldots$
standard form, in colors, 4 to $5 \mathrm{ft} \ldots \ldots \ldots \ldots \ldots \ldots$

Hippophae rhamnoides (Sea Buckthorn) $21 / 2$ to $3 \mathrm{ft} . \ldots . . \quad 1.50 \quad 12.00$

10.00

10.00

10.00

10.00

12.00

20.00

30.00

Hydrangea Arborescens grandiflora (Snowball Hydrangea) 18 to 24 in...................... 1.50

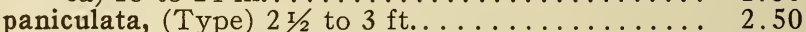

paniculata grandiflora, $2 \mathrm{I} / 2$ to $3 \mathrm{ft}$.................. 1.20

10.00

Hypericum aureum, 18 in................... 1.20

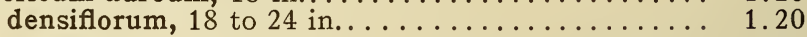

8.00

Ilex verticillata (Black Alder) 12 to 18 in........... 1.50

12.00

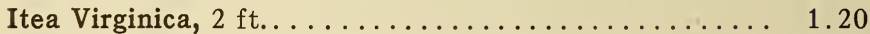

10.00

Kerria Japonica (Globe Flower) 15 to 18 in. . . . . . . . .

Japonica flora plena, 2 years. . . . . . . . . . . . .

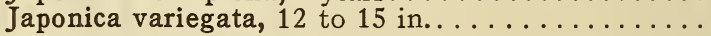

1.50

12.00

2.00

15.00

2.00

15.00

Lespedeza bicolor, 3 yrs. . . . . . . . . . . . . .

1. 20

10.00

Sieboldi (Desmodium penduliflorum) 3 yrs..........

2.50

15.00

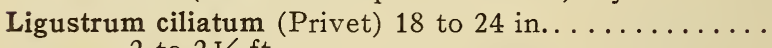

1.00

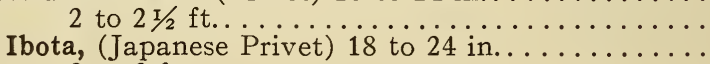

1. 20

7.00

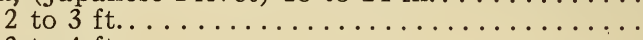

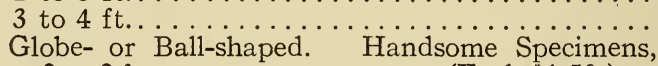

8.00

7.00

$1.00 \quad 8.00$

12.00 $2 \times 2 \mathrm{ft} . \ldots \ldots \ldots \ldots \ldots \ldots($ Each $\$ 1.50$. 


\section{Fan-Trained Fruit Trees}

FOR COVERING WALLS AND TRELLISES

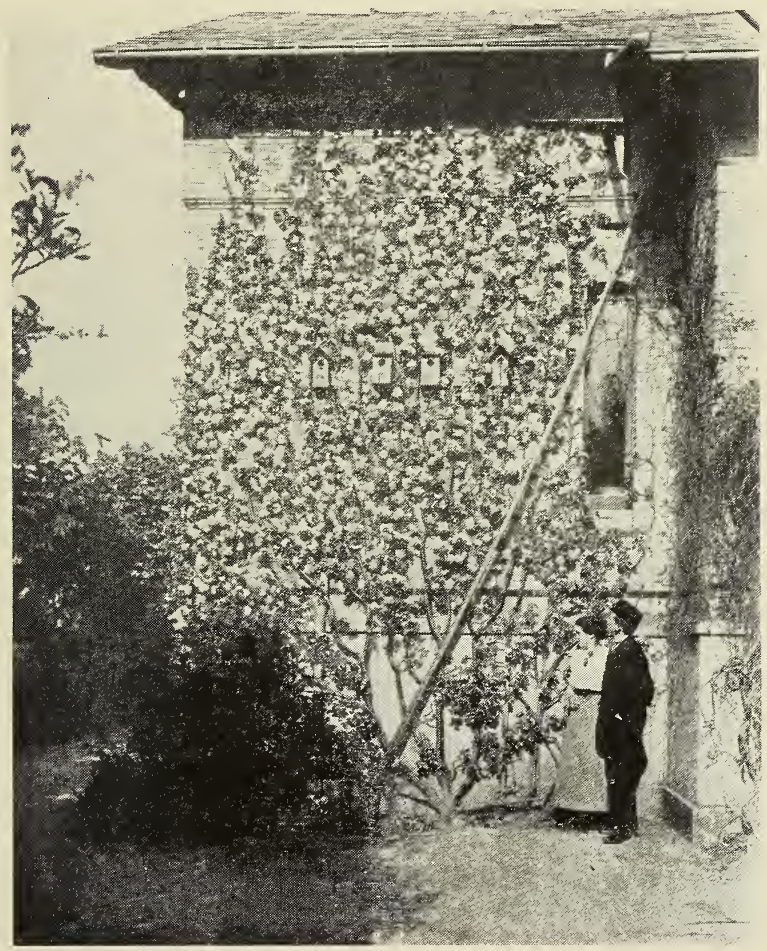

Offered by THE NEW ENGLAND NURSERIES CO.

BEDFORD, MASS. 


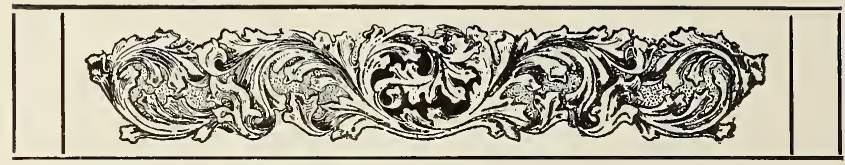

7 RAINED Fruit-trees, common in Europe, 1 where Cottage and Garden walls everywhere are covered and made attractive with various varieties of these interesting trees, can be grown equally successful in American gardens, and while the demand for them here is steadily incieasing they should be much more extensively grown. No City lot or yard is too small to accommodate one or more grown against the building or upon trellises, where they produce an abundance of the choicest fruit, generally far superior to that grown on ordinary standard trees. In sunny positions, Apples, Pears and Plums 
succeed best, while on north walls where sunlight is limited some varieties of Cherries can be grown with excellent success.

The trees we offer are well trained, from 4-5 feet high and can be relied upon to bear fruit the second summer after planting. Many of them will flower and attempt to bear the first year, but it is advisable to pick off the first year's blossoms as soon as they appear.

Apples, Pears, Plums and Cherries, we offer in fan-trained specimens at $\$ 3.50$ each, and Dwarf Pyramid trained trees, about 5 feet high at $\$ 2.50$, in all leading European and American varieties. Our pyramid trained trees are 5-6 years old, and like the fan-trained specimens will bear the first season after planting if desired. Being very hardy they can be successfully transplanted at any time 
after September 15, when they have finished their growth, and before the end of November, or in the Spring previous to the last of May.

\section{THE NEW ENGLAND NURSERIES Bedford, Mass.}


Ligustrum meadia, 2 to $3 \mathrm{ft} . \ldots \ldots \ldots \ldots \ldots \ldots \ldots \ldots$

Per 100

ovalifolium (California Privet) 18 to 24 in. ........

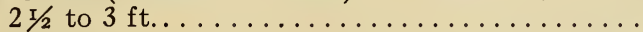

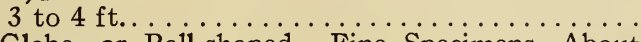

Globe- or Ball-shaped. Fine Specimens. About $21 / 2 \times 2 \mathrm{ft} . \quad$ (Each $\$ 1.50) \ldots \ldots \ldots \ldots \ldots$

vulgare (English Privet) $2 \mathrm{r} / 2 \mathrm{ft} . \ldots \ldots \ldots \ldots \ldots \ldots$

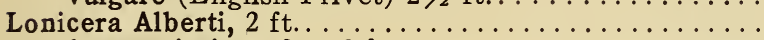

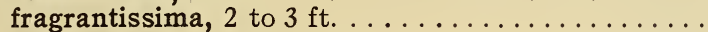

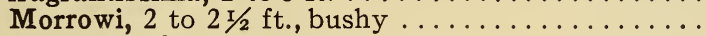

3 to $4 \mathrm{ft}$.

1.00

$\$ 9.00$

4.00

1.20

5.00

6.00

17.50

150.00

7.00

1. .00

1.80

15.00

1.00

8.00

tatarica (Bush Honeysuckle) 2 to $3 \mathrm{ft} . \ldots \ldots \ldots \ldots$

1.20

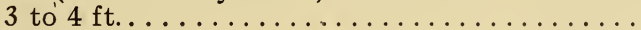

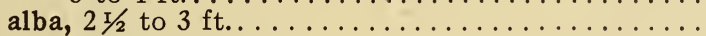

1.00

10.00

8.00

10.00

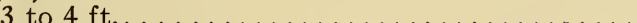

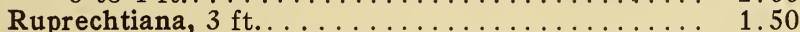

12.00

Lycium Barbarum (Box Thorn or Matrimony Vine) 2 to

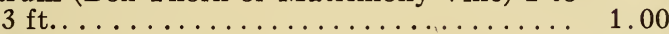

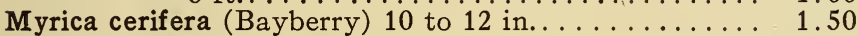

6.00

Philadelphus coronarius (Syringa or Mock Orange) 2 to $3 \mathrm{ft} . \ldots \ldots \ldots \ldots \ldots \ldots \ldots . \ldots \ldots \ldots$

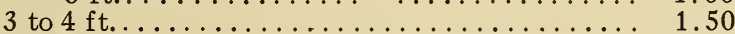

8.00

12.00

var. foliis aureis (Golden Syringa) 12 to 18 in.....

2.00

var. grandiflora, 2 to $2 \mathrm{I} / 2 \mathrm{ft} . \ldots \ldots \ldots \ldots \ldots \ldots$

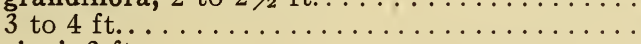

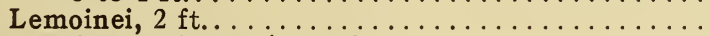

var. Avalanche, $11 / 2$ to $2 \mathrm{ft} . \ldots \ldots \ldots \ldots \ldots \ldots \ldots \ldots$

Candelabre hybridus, 2 to $3 \mathrm{ft} . \ldots \ldots \ldots \ldots \ldots \ldots$

Diantiflora, 2 to $3 \mathrm{ft} . \ldots \ldots \ldots \ldots \ldots \ldots \ldots \ldots$

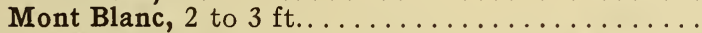

1.00

1.20

1.50

1. 20

1.50

1.50

1.50

Potintilla fruticosa (Shrubby Cinquefoil) 18 to 24 in. .... 1.50

Prunus pumila, 15 to 18 in................. 1.00

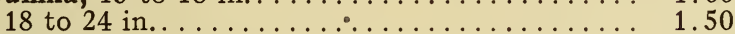

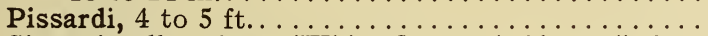

Sinensis alba plena (White-flowered Aimond) 2 to $3 \mathrm{ft}$. .

Sinensis rosea plena (Rose-flowered Almond) 2 to $3 \mathrm{ft} . \ldots \ldots \ldots \ldots \ldots \ldots \ldots \ldots$

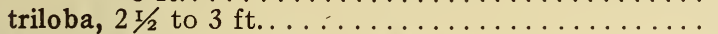

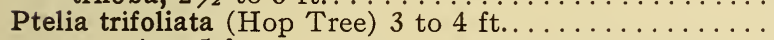

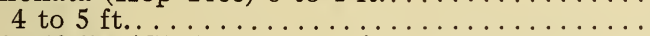

Pyrus arbutifolia (Chokeberry) $1 \mathrm{i} / 2$ to $2 \mathrm{ft} . \ldots \ldots \ldots \ldots$

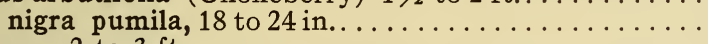
2 to $3 \mathrm{ft} . \ldots . \ldots \ldots \ldots \ldots$

Rhamnus catharticus (Buckthorn) 2 to $3 \mathrm{ft} \ldots \ldots \ldots \ldots$

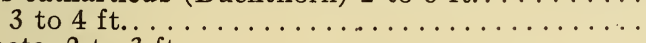

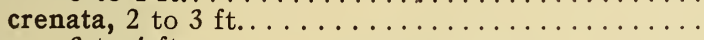
3 to $4 \mathrm{ft} . \ldots \ldots \ldots \ldots \ldots \ldots \ldots \ldots$

frangula or Carolinianus, $21 / 2$ to $3 \mathrm{ft} \ldots \ldots \ldots \ldots \ldots$

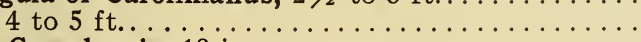

Rhodora Canadensis, 18 in. . . . . . . . . . . . . .

Rhodotypus kerrioides (White Kerria) 18 to 24 in......

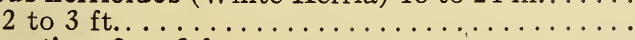

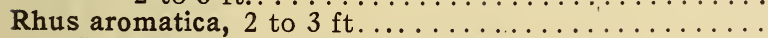

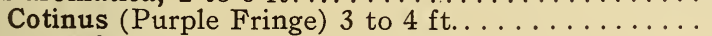

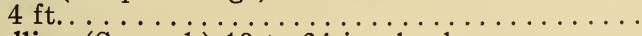

Copallina (Sumach) 18 to 24 in., bushy . . . . . . .

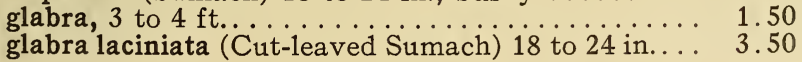

3.50

$2.00 \quad 15.00$

$2.00 \quad 15.00$

$2.00 \quad 18.00$

$1.00 \quad 6.00$

$1.50 \quad 7.00$

$2.00 \quad 18.00$

$1.00 \quad 8.00$

1. $20 \quad 10.00$

$1.20 \quad 7.00$

$1.50 \quad 10.00$

$1.20 \quad 10.00$

$2.00 \quad 15.00$

$1.20 \quad 10.00$

$1.80 \quad 15.00$

$4.00 \quad 35.00$

$1.00 \quad 8.00$

$1.20 \quad 10.00$

2.50

$2.00 \quad 15.00$

2.50

$1.50 \quad 12.00$

1. $50 \quad 8.00$ 
DECIDUOUS SHRUBS-(Continued)

Rhus typhina, 4 to $5 \mathrm{ft}$.

Ribes alpinum (Mountain Currant) $1 \mathrm{i} / 2 \mathrm{ft} . \ldots \ldots \ldots \ldots$ aureum (Flowering Currant) 2 to $3 \mathrm{ft} . \ldots \ldots \ldots \ldots$ sanguineum, 2 to $3 \mathrm{ft} . \ldots \ldots \ldots \ldots \ldots \ldots \ldots$

Robinia hispida (Rose Acacia) 2 to $3 \mathrm{ft} . \ldots \ldots \ldots \ldots \ldots$

Rubus odorata (Flowering Raspberry) 2 to $2 \mathrm{I} / 2 \mathrm{ft} . \ldots .$. .

Rosa blanda, 15 to 18 in.

1.50

12.00

$2.00 \quad 15.00$

$1.20 \quad 10.00$

$2.00 \quad 15.00$

$1.50 \quad 12.00$

$1.50 \quad 12.00$

$1.20 \quad 10.00$

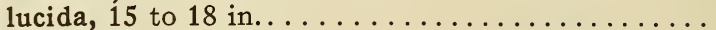

multiflora, 15 to 18 in. . . . . . . . . . . . .

1.20

10.00

rubiginosa, 2 to $2 \mathrm{r} / 2 \mathrm{ft}$., strong (per M. $\$ 60.00$ )....

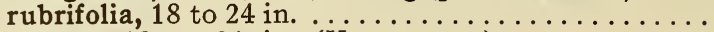

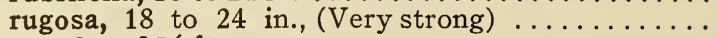

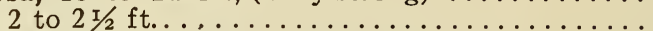
rugosa alba, 18 to 24 in..................

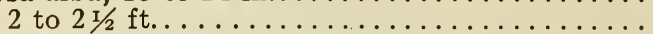

1. 20

$1.00 \quad 7.00$

$1.50 \quad 12.00$

$1.00 \quad 8.00$

$1.20 \quad 10.00$

$1.50 \quad .12 .00$

$2.00 \quad 15.00$

" setigera, 2 to $3 \mathrm{ft} . \ldots \ldots \ldots \ldots \ldots \ldots \ldots \ldots \ldots$ 3 to $4 \mathrm{ft} . \ldots \ldots \ldots \ldots \ldots \ldots \ldots \ldots \ldots$

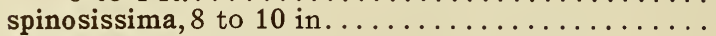

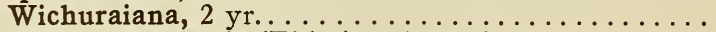

Sambucus Canadensis (Elder) $11 / 2$ to $2 \mathrm{ft} . \ldots \ldots \ldots \ldots$. . . . . . . nigra aurea (Golden Elder) 2 to $3 \mathrm{ft} . \ldots \ldots \ldots \ldots \ldots$ racemosus or pubens, 2 to $3 \mathrm{ft} . \ldots \ldots \ldots \ldots \ldots$

Shepherdia argentea (Buffalo Berry) 3 to $4 \mathrm{ft} . \ldots \ldots \ldots$. Snowberry. (See Symphoricarpos)

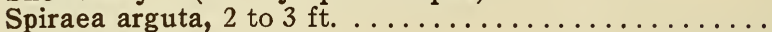
Billardi, $2 \mathrm{t} / 2$ to $3 \mathrm{ft} . \ldots \ldots \ldots \ldots \ldots \ldots \ldots$

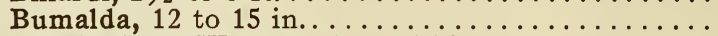
var. Anthony Waterer, 12 to 15 in............. Fortunei roseum, 2 to $3 \mathrm{ft} . \ldots \ldots \ldots \ldots \ldots$ opulifolia (Nine Bark) $3 \mathrm{ft} . \ldots \ldots \ldots \ldots \ldots \ldots \ldots$

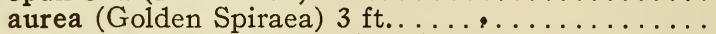
prunifolia (Bridal Wreath) $2 \mathrm{x} / 2$ to $3 \mathrm{ft} . \ldots \ldots \ldots$. . .

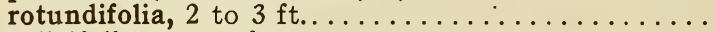
salicifolia, 2 to $3 \mathrm{ft} . \ldots \ldots \ldots \ldots \ldots \ldots \ldots$

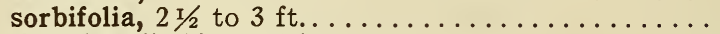

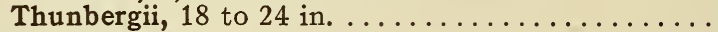

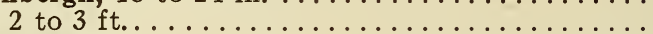

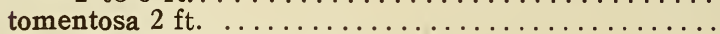

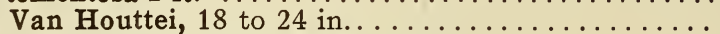
2 to $3 \mathrm{ft}$. (per M. $\$ 80.00) \ldots \ldots \ldots \ldots \ldots$

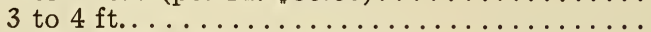

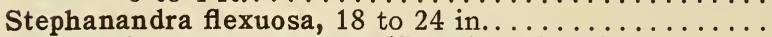
Symphoricarpos racemosus (Snowberry) 24 in........... 2 to $3 \mathrm{ft}$.

vulgaris (Indian Currant) 2 to $3 \mathrm{ft.} \ldots \ldots \ldots \ldots \ldots$ Syringa Japonica (Japanese White Lilac) 4 to $5 \mathrm{ft}$....... 5 to $6 \mathrm{ft}$.

1.00

2.00

2.00

8.00

$\begin{array}{ll}1.00 & 8.00\end{array}$

$\begin{array}{ll}1.20 & 10.00\end{array}$

$1.80 \quad 10.00$

2.00

2.00

1. 20

10.00

1.20

10.00

$1.00 \quad 8.00$

$\begin{array}{ll}1.50 & 12.00\end{array}$

1.50

1. 20

1. 20

1.50

1.50

1. 00

1. 20

1. 20

1.50

1.00

1.00

1.20

1.50

1. 20

1.00

1. 20

1. 20

4.00

5.00

1.80

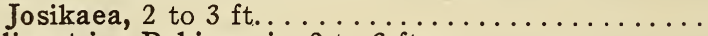

ligustrina Pekinensis, 2 to $3 \mathrm{ft} . \ldots \ldots \ldots \ldots \ldots \ldots$

Persica, $21 / 2$ to $3 \mathrm{ft} . \ldots \ldots \ldots \ldots \ldots \ldots$

alba, $21 / 2$ to $3 \mathrm{ft} . \ldots \ldots \ldots \ldots \ldots \ldots \ldots \ldots \ldots$

Rothomagensis (Rouen Lilac) 2 to $3 \mathrm{ft} . \ldots \ldots \ldots$. . . .

villosa, $3 \mathrm{ft} . \ldots \ldots \ldots \ldots \ldots \ldots \ldots \ldots . \ldots \ldots \ldots$

vulgaris (Common Lilac) $21 / 2$ to $3 \mathrm{ft} . \ldots \ldots \ldots \ldots$

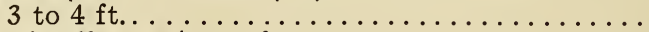

vulgaris alba, $2 \mathrm{i} / 2$ to $3 \mathrm{ft} . \ldots \ldots \ldots \ldots \ldots \ldots \ldots \ldots \ldots$

3.00

2.00

2.00

2.00

8.00

10.00

12.00

7.00

8.00

10.00

8.00

7.00

10.00

12.00

10.00

8.00

10.00

8.00

30.00

40.00

$2.00 \quad 15.00$

$1.50 \quad 10.00$

$2.00 \quad 15.00$

$1.50 \quad 12.00$

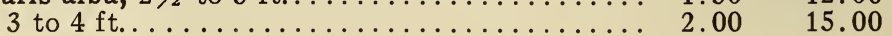

15.00

18.00

15.00

15.00 


\section{French or Hybrid Lilacs}

Price. 18 inches, $\$ 2.00$ per 10 . 2 to $3 \mathrm{ft}$., $\$ 2.50$ per 10 .

\section{Syringa var. Alphonse Lavallee}

var. Charles $X$

var. Frau Bertha Dammann

var. La Marque

var. Ludwig Spaeth

var. Belle de Nancy

var. Toure de Auvergne

var. Emile Lemoine

var. Mad. Casimir Perier

var. Mad. Lemoine

var. Marie Le Graye

var. Michel Buchner

var. President Grevy

Per 100

$\$ 1.50$

$\$ 12.00$

Gallica, 3 to $4 \mathrm{ft} . \ldots \ldots \ldots \ldots \ldots \ldots \ldots \ldots \ldots$

Vaccinium corymbosum (Blueberry) 2 to $3 \mathrm{ft}$..........

Pennsylvanicum (Dwarf Huckleberry) 12 to 15 in.. .

Viburnum acerfolium, 18 to 24 in.

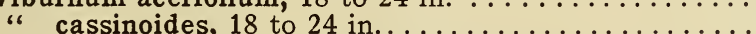

" dentatum (Arrow-wood) 2 to $3 \mathrm{ft} . \ldots \ldots \ldots \ldots \ldots$. . . .

3 to $4 \mathrm{ft} . \ldots \ldots \ldots \ldots \ldots \ldots \ldots$

" lantana (Wayfaring Tree) 2 to $3 \mathrm{ft} . \ldots \ldots \ldots \ldots$. . . .

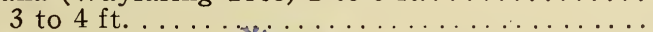

" lentago (Sheepberry) 2 to 3 ft. . . . . . . . .

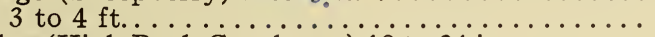

" opulus (High Bush Cranberry) 18 to 24 in.........

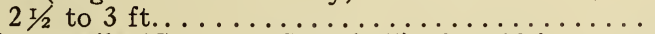

" opulus sterile (Common Snowball) 12 to 18 in.....

" plicatum (Japanese Snowball) $2 \mathrm{ft} . . . \ldots \ldots \ldots \ldots$.

" tomentosum, 2 to $21 / 2 \mathrm{ft} . \ldots \ldots \ldots \ldots \ldots \ldots \ldots \ldots$

Xanthorrhiza apiifolia (Yellow-root) Whole clumps, large. Strong divisions (per M. $\$ 35.00) \ldots \ldots \ldots \ldots$.

\section{Standard Shrubs}

$\begin{array}{llr}\text { Hibiscus (Tree Althaea) } 4 \text { to } 5 \mathrm{ft} \ldots \ldots \ldots \ldots \ldots . \$ & \begin{array}{r}\text { Each } \\ .50\end{array} & \begin{array}{r}\text { Per } 10 \\ \$ .00\end{array} \\ \text { Hydrangea P. G., } 3 \text { to } 4 \mathrm{ft} . \ldots \ldots \ldots \ldots \ldots \ldots & .40 & 3.50 \\ \text { Roses, all colors, } 4 \text { to } 5 \mathrm{ft} . \ldots \ldots \ldots \ldots \ldots \ldots & .50 & 4.50\end{array}$

\section{Vines and Climbing Shrubs}

Actinidia arguta, 3 yrs. ................ $\$ 2.00$

Akebia quinata, 3 yrs................... 2.00

Ampelopsis quinquefolia (Woodbine) 3 yrs......... 1.00

var. Engelmanni, 3 yrs................ 1.20

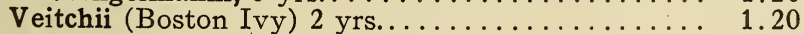


Aristolochia sipho (Dutchman's Pipe) 3 years .......\$2.50

$\$ 20.00$

Bignonia. (See Tecoma)

Celastrus scandens (Bittersweet) 3 yrs...........

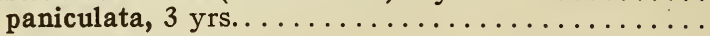

1.00

8.00

Clematis coccinea, 3 yrs. . . . . . . . . . . . .

1. 20

10.00

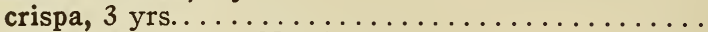

1.20

paniculata, 2 yrs., No. $1 \ldots \ldots \ldots \ldots \ldots \ldots \ldots \ldots$

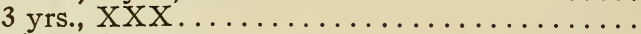

1.00

10.00

1.20

8.00

Virginiana, 3 yrs. .

1.20

10.00

Virginiana, var. coerulea or New England (The new light blue or Hyacinth flowered Clematis). A rampant grower, free flowering and

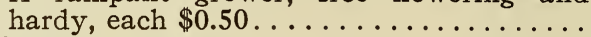

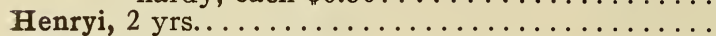

Jackmani, 2 yrs., strong. . . . . . . . . . . . .

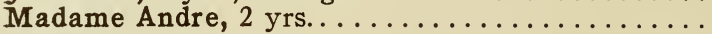

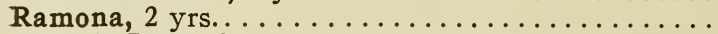

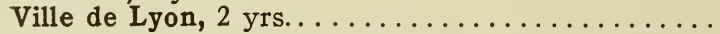

Dolichos Japonica (Kudzu Vine) 2 yrs. ............

Humulus Lupulus (Hop Vine) 2 yrs............

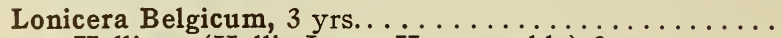

Halliana (Hall's Japan Honeysuckle) 3 yrs........

sempervirens (Scarlet Trumpet Honeysuckle) 3 yrs.

Lycium Barbarum (Box Thorn or Matrimony Vine) 2 to

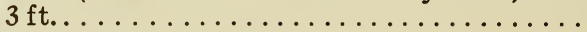

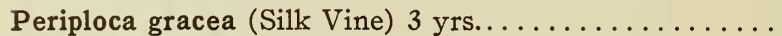

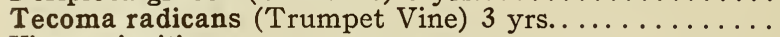

Vites coignitia.

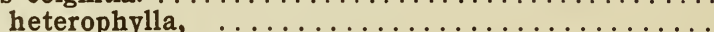

Wistaria Chinensis (Blue Wistaria) 2 yrs., strong......

Chinensis alba (White Wistaria) 2 yrs., strong....

multijuga (Japanese dark blue).............

$\begin{array}{rr}4.00 & 35.00 \\ 2.50 & 20.00 \\ 2.50 & 20.00 \\ 2.50 & 20.00 \\ 2.50 & 20.00 \\ 2.50 & 20.00 \\ 2.50 & 20.00 \\ 1.00 & 8.00 \\ 1.50 & 12.00 \\ 1.20 & 9.00 \\ 1.20 & \\ & \\ 1.00 & 8.00 \\ 2.00 & 15.00 \\ 1.00 & 5.00 \\ 3.00 & \\ 2.50 & \\ 2.50 & 20.00 \\ 2.50 & 20.00 \\ 6.00 & .\end{array}$

\section{Hardy Herbaceous Perennials, Grasses and Ferns}

Our stock is young and thrifty and whether from the field or from pots, the plants we send out will flower the first season. We do not send out old clumps or small seedlings.

Prices: Twenty-five or more plants of one variety will be supplied at hundred rates. Two or more plants will be supplied at the rate per ten. Single plants will not be furnished at less than 10 cents each.

Full descriptions will be found in our General Catalog, a copy of which will be sent upon application.

Acanthus mollis, purple, August, 3 to $4 \mathrm{ft} \ldots \ldots \ldots \ldots \ldots 1.00 \quad \$ 7.00$

Achillea Aegyptica (Yarrow) yellow, July to Sept., 20 in. $\quad .70 \quad \$ 5.00$

The Pearl, double white, July, $11 / 2$ to $2 \mathrm{ft}$........ $\quad .70 \quad 5.00$

mill efolium roseum, pink, July to October, 18 in... $\quad .80 \quad 6.00$

tomentosa, golden yellow, July, 8 to $10 \mathrm{in..........8} \quad .80 \quad 6.00$

Aconitum autumnale (Monkshood) blue, June, $4 \mathrm{ft} . \ldots . .61 .20 \quad 100$

uncinatum........................ $1.20 \quad 10.00$ 
HARDY HERBACEOUS PERENNIALS, ETC.-(Continued)

Acorus calamus (Sweet Flag) $2 \mathrm{ft} . \ldots \ldots \ldots \ldots \ldots \ldots$

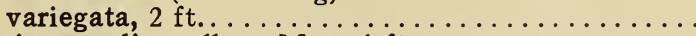

Adonis vernalis, yellow, May, $1 \mathrm{ft} . \ldots \ldots \ldots \ldots \ldots \ldots$

Aegopodium podograria variegata (Variegated Goutweed) 8 to 10 in., white........................

Agrostemma coronaria, crimson, June to August, 2 to $3 \mathrm{ft}$

Flos-Jovis, rose, June and July, 1 to $2 \mathrm{ft} . . . \ldots \ldots$

Aira coerulea variegata (Hair Grass) $11 / 2 \mathrm{ft} . \ldots \ldots \ldots$.

Ajuga reptans (Bugle), purple, May, 3 to 4 in.........

Alstroemeria aurantiaca (Peruvian Lily) orange, July to September, 2 to $3 \mathrm{ft} . \ldots \ldots \ldots \ldots \ldots$.

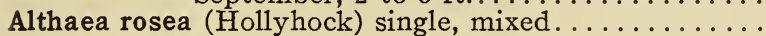

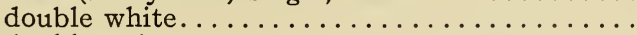

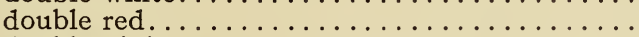

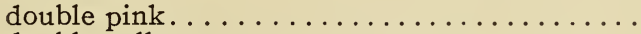

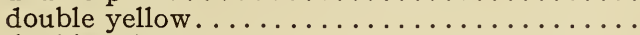

double salmon . . . . . . . . . . . . . .

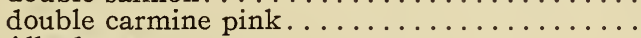

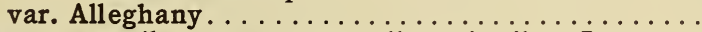

Alyssum saxatile compactum, yellow, April to June... .

Anchusa Italica var. Dropmore, blue, July to October,

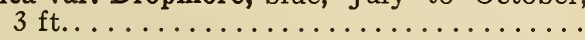

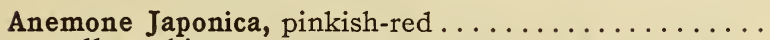

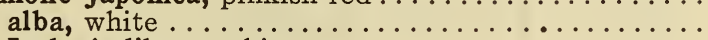

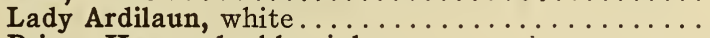

Prince Henry, double pink. . . . . . . . . .

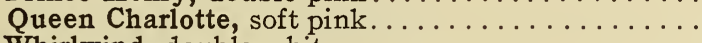

Whirlwind, double white $\ldots \ldots \ldots \ldots \ldots \ldots \ldots$

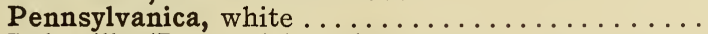

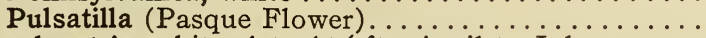

sylvestris, white, 1 to $1 \mathrm{r} / 2 \mathrm{ft}$., April to July.......

Anthemis Kelwayii, yellow, June to October, 2 to $3 \mathrm{ft}$. .

Anthericum lilastrum major (St. Bruno's Lily) white, May and June, 18 in . . . . . . . . . . . . .

Per 10 Per 100

$1.00 \quad 7.00$

$1.00 \quad 8.00$

1.20

$.80 \quad 6.00$

$.70 \quad 5.00$

$.70 \quad 5.00$

$1.00 \quad 8.00$

$.70 \quad 5.00$

$1.20 \quad 10.00$

$.70 \quad 5.00$

$.80 \quad 6.00$

$.80 \quad 6.00$

$.80 \quad 6.00$

$.80 \quad 6.00$

$.80 \quad 6.00$

$.80 \quad 6.00$

$1.00 \quad 8.00$

$.80 \quad 6.00$

$1.00 \quad 8.00$

$1.00 \quad 6.00$

$100 \quad 6.00$

$1.00 \quad 6.00$

$1.00 \quad 6.00$

$1.00 \quad 6.00$

$1.00 \quad 6.00$

$.80 \quad 6.00$

$1.00 \quad 8.00$

$.80 \quad 6.00$

$.70 \quad 6.00$

$1.00 \quad 8.00$

Aquilegia Canadensis (Columbine) scarlet and yellow, April to June, $2 \mathrm{ft} . . . \ldots \ldots \ldots \ldots \ldots$.

chrysantha, golden yellow, May to August, $3 \mathrm{ft} . .$.

coerulea (Rocky Mt. Columbine) blue and white, $1 \mathrm{ft}$

Formosa or Californica, orange yellow, May to July.

hybrida, various colors, May to July, $3 \mathrm{ft} . . . . .$. .

glandulosa, blue and white, April to May, $112 \mathrm{ft}$. . . . .

Skinnerii, crimson, May and June, $2 \mathrm{ft} . . . \ldots \ldots$

vulgaris, various colors, April to June, $2 \mathrm{ft} . \ldots \ldots$. .

alba, pure white, April to June, 2 to $3 \mathrm{ft} . . . . . .$.

flora plena, double, various colors, May to July, $3 \mathrm{ft}$

Arabis albida (Rock Cress) white, April to May, 6 to 9 in.

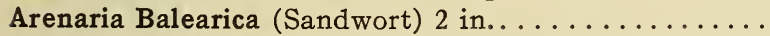

Armeria cephalotes rubra (Sea Pink) crimson, June and

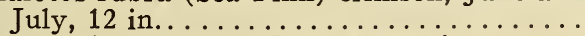

maritima, purple, May and June, 4 to 6 in.........

$1.00 \quad 8.00$

$.80 \quad 6.00$

$1.00 \quad 8.00$

$.80 \quad 6.00$

$.80 \quad 6.00$

$.80 \quad 6.00$

$1.00 \quad 8.00$

$.80 \quad 6.00$

1.00

1.00

$.80 \quad 5.00$

$.80 \quad 6.00$

$.70 \quad 5.00$

$.70 \quad 5.00$

$\begin{array}{lll}\text { Lauchiana, crimson, April to July, } 4 \text { to } 6 \text { in........... } & .70 & 5.00 \\ \text { Lauchiana var. robusta, crimson, April to July, } 12 \text { in. } & .90 & 7.00\end{array}$

Artemisia absynthia (True Wormwood) $2 \mathrm{ft} \ldots \ldots \ldots \ldots . . . .60$

dracunculus (Tarragon) $2 \mathrm{ft} \ldots \ldots \ldots \ldots \ldots \ldots \ldots . . .60$

frigida (Small Southernwood) $1 \mathrm{ft} . \ldots \ldots \ldots \ldots \ldots . .9 . .90$

6.00 
HARDY HERBACEOUS PERENNIALS, ETC,-(Continued)

Artemisia Stellariana, 18 in

Per 10

Per 100

Pontica, $1 \mathrm{ft} . \ldots \ldots \ldots \ldots \ldots$

\$. 80

Arundo Donax variegata (Variegated Reed) 6 to $8 \mathrm{ft} . .$. .

.80

Ascelpias incarnata pulchra, purplish-red, July, 3 to $4 \mathrm{ft}$.

tuberosa (Butterfly-weed) orange-scarlet, July and

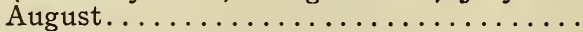

Asperula odorata (Sweet Woodruff) ............. 1.00

$\$ 7.00$

2.00

.80

.90

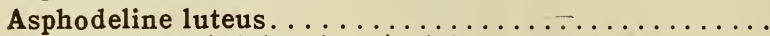

1.20

Aster Alpinus (Alpine Aster) violet, 6 to 8 in., May....

.80

6.00

" amellus Bessarabicus, purplish-blue, August, $2 \mathrm{ft}$. .

.80

6.00

"Caliope, violet, July and August, $3 \mathrm{ft}$............

.70

5.00

“ Lady Trevellyn, white, September to November, $4 \mathrm{ft}$.

.70

5.00

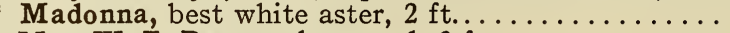

.70

5.00

Mrs. W. F. Raynor, large red, $3 \mathrm{ft} . \ldots \ldots \ldots \ldots$. . . .

.80

6.00

“ multiflorus, white, October and November, $2 \mathrm{ft} . \ldots$

.70

5.00

“ Novae Angliae, August and September, $4 \mathrm{ft} . . . .$. .

" roseus, rose and crimson, $4 \mathrm{ft} . \ldots \ldots \ldots \ldots \ldots \ldots$

“ W. F. Burbidge, heliotrope, August and September,

\section{New Hardy Asters}

The following three varieties are, undoubtedly, the finest yet introduced.

$\begin{array}{rrrr} & \text { Per } 10 & \text { Per } 100 \\ \text { A. Novelty. Light blue with yellow center.......... } \$ 1.20 & \$ 10.00 \\ \text { A. Pink Beauty. Blush pink with dark center..... } & 1.20 & 10.00 \\ \text { A. Spectabilis var. Nenco. Deep lavender. Individual } & & \\ \text { flowers 2 inches across.................. } & 1.20 & 10.00\end{array}$

(For other new and improved sorts of Hardy Asters, see our General Catalog.)

Astilbe (See Spiraea)

Aubretia deltoides (Rock Cress) May, 3 to 6 in....... \$1.20

Baptisia australis, dark blue, June and July, $3 \mathrm{ft} . \ldots . . .9 .90$

Betonica rosea superba, rose, July, $1 \mathrm{ft} . \ldots \ldots \ldots \ldots . .80$

$\$ 7.00$

6.00

Bellis perennis (English Daisy) pink and white, 6 in....

Bocconia cordata, whitish-green, August, $6 \mathrm{ft} . . . \ldots \ldots$.

Boltonia asteroides, white, September and October, $5 \mathrm{ft}$.

latisquama, lavender-lilac, August and September,

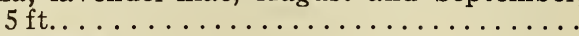

latisquama, nana. . . . . . . . . . . . . . . .

.60

5.00

1.00

8.00

$.60 \quad 4.00$

$.80 \quad 6.00$

$1.00 \quad 8.00$

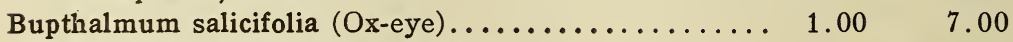

Callirhoe involucreta (Poppy Mallow) ............ $\quad .80 \quad 6.00$

Campanula calycanthema (Cup-and-Saucer) pink, white and

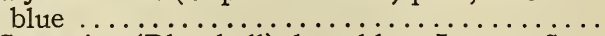

Campanula Carpatica (Biue-beli) deep blue, June to Sep-

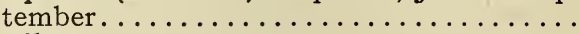

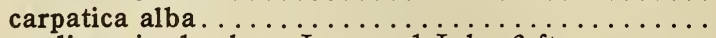

media, mixed colors, June and July, $3 \mathrm{ft} . \ldots \ldots \ldots$ white.

$1.00 \quad 8.00$

$1.00 \quad 6.00$

$1.00 \quad 7.00$

$.80 \quad 5.00$

$.80 \quad 5.00$ 


\section{HARDY HERBACEOUS PERENNIALS, ETC.-(Continued)}

Campanula media, mixed colors, June and July $\mathbf{3} \mathrm{ft}$.

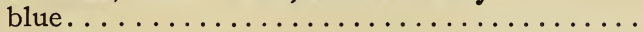

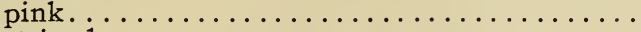

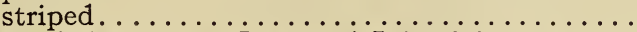

Persicaefolia, purple, June and July, $3 \mathrm{ft} . \ldots \ldots \ldots$

var. Moerheimi, double white, June and July, $2 \mathrm{ft}$.

pyramidalis, deep blue, July and August, 4 to $5 \mathrm{ft}$.

rotundifolia (Blue Bell of Scotland), per M. $\$ 55.00$. .

Trachlium, deep blue, June and July, $2 \mathrm{ft} . . . \ldots$.

Cassia Marylandica, yellow, July and September, $4 \mathrm{ft} .$. .

Catananche coerulea (Cupid's Dart)...............

Centaurea macrocephala, deep yellow, July to September,

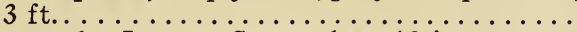

Montana, purple, June to September, 18 in..........

nigra variegata, blue, July to September, 18 in.....

Centranthus ruber (Red Valerian) crimson, June to August, $2 \mathrm{ft} . \ldots \ldots \ldots \ldots \ldots \ldots \ldots$.

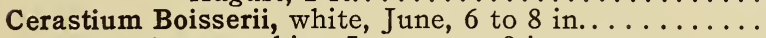

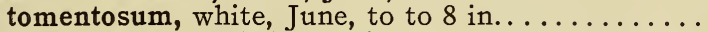

Chelone Lyonii, purplish-red, August, $2 \mathrm{ft} . . . . . . .$.

Chrysanthemum latifolium, white, August and Septem-

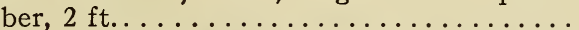

leucanthemum hybridum (Shas ta Daisy) white, all

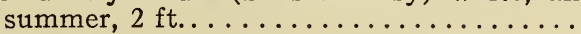

var. Californica, white, tinted yellow, $2 \mathrm{ft} . \ldots \ldots$.

Westralia, creamy white, $3 \mathrm{ft} . \ldots \ldots \ldots \ldots \ldots$. maximum, King Edward, white, all summer, $2 \mathrm{ft}$. .

Hardy Garden varieties, all colors ............

Cimicifuga racemosa, white, July, 4 to $5 \mathrm{ft} . . \ldots \ldots \ldots \ldots$

Clematis Davidiana, light blue, August and September, $4 \mathrm{ft} . \ldots \ldots \ldots \ldots \ldots \ldots \ldots \ldots \ldots \ldots$. . . . recta, white, September and October, $3 \mathrm{ft} . \ldots \ldots \ldots$ Convallaria majalis (Lily of the Valley) clumps........ Coreopsis grandiflora, yellow, June to September, $3 \mathrm{ft}$. . lanceolata, yellow, June to September, $2 \mathrm{ft}$. . . . . . .

Coreopsis verticillata, lemon-yellow, June to September,

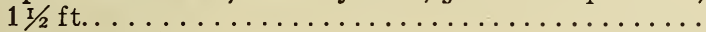

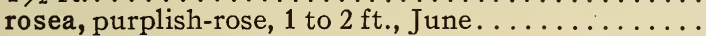

Per 10 Per 100

$\$ .80$

$\$ 5.00$

.80

.80

.90

5.00

1.00

1.00

1.00

1.00

5.00

7.00

9.00

7.00

7.00

5.00

$.80 \quad 6.00$

$1.00 \quad 7.00$

$.80 \quad 6.00$

$1.00 \quad 8.00$

$1.00 \quad 7.00$

$1.00 \quad 6.00$

$1.00 \quad 6.00$

$.80 \quad 5.00$

$1.00 \quad 8.00$

$.70 \quad 5.00$

$.90 \quad 7.00$

$.90 \quad 7.00$

$1.00 \quad 8.00$

$.80 \quad 5.00$

1.50

$\begin{array}{ll}1,00 & 8.00\end{array}$

$1.20 \quad 10.00$

$2.00 \quad 18.00$

$.70 \quad 5.00$

$.70 \quad 5.00$

$1.00 \quad 6.00$

$1.00 \quad 6.00$

Cypripedium spectabilis (Lady Slipper) . . . . . . . . .

Delphinium Bella Donna, sky blue, 1 to $1 \mathrm{r} / 2 \mathrm{ft} . \ldots \ldots$. .

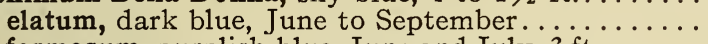

formosum, purplish-blue, June and July, $3 \mathrm{ft} . . . \ldots \ldots$

hybridum, all colors, mixed, June to September, $3 \mathrm{ft}$.

Sinensis, light blue, July and August, $2 \mathrm{ft}$........

var. alba, white, July and August, 2 ft...........

$1.00 \quad 8.00$

$1.00 \quad 8.00$

$.80 \quad 6.00$

$1.00 \quad 6.00$

$.70 \quad 5.00$

$.60 \quad 4.00$

$.70 \quad 5.00$

Dianthus barbatus (Sweet William) crimson, pink and white, June and July, $1 \mathrm{x} / 2 \mathrm{ft} . \ldots \ldots \ldots \ldots$

deltoides (Maiden Pink) deep pink, 6 to 8 in......

plumarius (Scotch Pine) June, 9 in..............

.60

4.00

.80

6.00

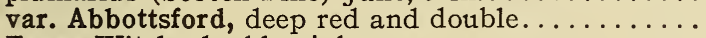

.70

5.00

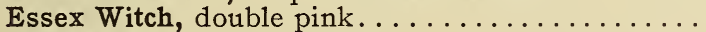

Her Majesty, double white. . . . . . . . . . . .

Homer, rosy red, double. . . . . . . . . . . .

Juliette, crimson and white variegated...........

.80

.80

6.00

.80

6.00

6.00

Mrs. Sinkins, double white...............

New Mound, blush pink, double............

.80

6.00

7.00

$.80 \quad 6.00$

Perpetual Snow, double white, new and fine......

.80

.80

6.00

6.00 


\section{HARDY HERBACEOUS PERENNIALS, ETC.-(Continued)}

Dianthus Souvenir de Sale, soft pink, double........

Semperflorens, dark pink, all summer...........

White Reserve, double white, new and fine.........

(For improved and new varieties of Hardy Garden Pinks, see our General Catalog.)

Dictamnus fraxinella (Gas Plant) red, May and June, 3

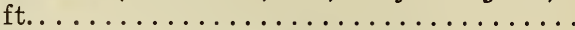

Dicksonia punctilobula (Gossamer Fern) $2 \mathrm{ft} . \ldots \ldots \ldots$

Dicentra eximia, purplish-red, all summer, 18 in. . . . . . . spectabilis (Bleeding Heart) crimson and white, April to June, $2 \mathrm{ft} . \ldots \ldots \ldots \ldots \ldots \ldots$

Digitalis gloxiniaeflora (Foxglove) white and pink, June and July, $3 \mathrm{ft} . \ldots \ldots \ldots \ldots \ldots \ldots$

var. alba, white, June and July, $3 \mathrm{ft} . \ldots \ldots \ldots \ldots$ grandiflora, yellow, June and July, $3 \mathrm{ft} . \ldots \ldots \ldots$. purpurea, purple and white, June and July, $3 \mathrm{ft}$. . .

Dodecatheon Media (American Cowslip) rosy purple, April and June, 12 in...............

Echinacea purpurea, reddish purple, August and September, $3 \mathrm{ft} . \ldots \ldots \ldots \ldots \ldots \ldots \ldots \ldots$. . . . . . . . . .

Echinops Ritro, steel blue, July and September, $3 \mathrm{ft} . .$.

Epilobium angustifolium (Willow Herb) magenta, 4 to 5

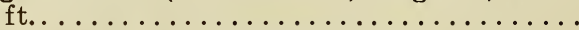

Erianthus Ravennae (Ravenna Grass) $3 \mathrm{ft} . . . \ldots \ldots \ldots$ Eryngium amethystinum, Amethyst blue, July and August, $3 \mathrm{ft} . \ldots \ldots \ldots \ldots \ldots \ldots \ldots$. aquaticum, ivory white, June to October, $4 \mathrm{ft}$........

Eulalia gracillima (Hardy Pampas Grass) 4 to $5 \mathrm{ft}$..... Japonica, $4 \mathrm{ft} . \ldots \ldots \ldots \ldots \ldots \ldots \ldots \ldots \ldots$ Japonica variegata, $4 \mathrm{ft} . \ldots \ldots \ldots \ldots \ldots \ldots \ldots \ldots \ldots$ zebrina (Zebra Grass) $4 \mathrm{ft} . \ldots \ldots \ldots \ldots \ldots \ldots \ldots$

Eupatorium purpureum, purple, October, 4 to $5 \mathrm{ft}$...... Euphorbia corollata, white, July and August, $2 \mathrm{ft} . . .$. . Festuca glauca (Fescue Grass) 8 to 10 in., per M. $\$ 35.00$.

Funkia grandiflora, pure white, July and September, $2 \mathrm{ft.}$.

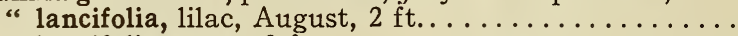

" lancifolia aurea, 2 ft. . . . . . . . . . . . . . . . .

“ undulata variegata, white variegated, $1 \mathrm{ft} . . . \ldots \ldots$. .

“ Sieboldiana, pale lilac, June and July, $2 \mathrm{ft}$. .......

Gaillardia aristata, yellow, June to November, $2 \mathrm{ft} . .$. . hybridum, orange, June to November, $2 \mathrm{ft} . . . . .$.

Galtonia candicans, white, August, $4 \mathrm{ft} . . \ldots \ldots \ldots$. . . .

Geranium platypetalum, deep violet, July and August, 1 I $/ 2$

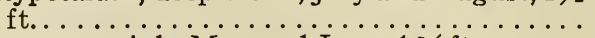
maculatum, rosy pink, $\mathrm{M}$ ay and June, $1 \mathrm{i} / 2 \mathrm{ft} . \ldots \ldots$

Gillenia trifoliata, white, July, $3 \mathrm{ft} . \ldots \ldots \ldots \ldots \ldots$

Gypsophila paniculata, white, July and August, $2 \mathrm{ft}$... repens, white, June to September, 6 in..........

Stevenii, white, June and July, 2 ft. . . . . . . . .

Helenium autumnale superbum, clear yellow, September, $5 \mathrm{ft} . \ldots \ldots \ldots \ldots \ldots \ldots . \ldots \ldots$

Bigelowi, bright yellow, August and September, $5 \mathrm{ft}$.. grandicephalum striatum, crimson and orange, Aug-

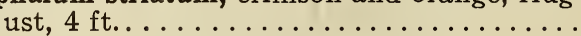
Hoopesii, orange yellow, May and June, $3 \mathrm{ft} . \ldots \ldots$ 


\section{HARDY HERBACEOUS PERENNIALS, ETC.-(Continued)}

Helianthemum angustifolium, bright yellow, July and

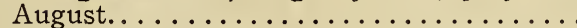
hyssopifolium, copper-yellow, June and July, 6 in. vulgare citrinum, bright yellow, June and July, 6 in. . Helianthus decapetalus (Sunflower) yellow, September

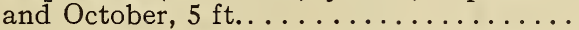

laetiflorus, orange-yellow, July to October, $5 \mathrm{ft} . .$. Meteor D'or, double yellow, September to November, $4 \mathrm{ft} . \ldots \ldots \ldots \ldots \ldots \ldots \ldots$. . . . . . . . .

Miss Mellish, semi-double, orange.......... mollis, lemon yellow, August and September, $5 \mathrm{ft}$. . multiflorus flore pleno, double yellow, September to November, 4 ft................. tuberosa (Jerusalem Artichoke) yellow, September to October, $4 \mathrm{ft} . . \ldots \ldots \ldots \ldots \ldots \ldots$.

Helleborus niger major (Christmas Rose) white, December and January, $1 \mathrm{ft} . \ldots \ldots \ldots \ldots \ldots \ldots$

Heliopsis laevis, orange yellow, June to October, $4 \mathrm{ft} .$. pitcheriana, deep orange, July to September, $3 \mathrm{ft}$. .

Hemerocallis aurantiaca major, orange yellow, July and August, $3 \mathrm{ft} . \ldots \ldots \ldots \ldots \ldots \ldots \ldots \ldots \ldots$ fulva (Homestead Lily) orange, July and August, $3 \mathrm{ft}$. var. Gold Dust, golden yellow, June and July, $3 \mathrm{ft} . .$. . Graminea, orange yellow, July and August, $3 \mathrm{ft}$.... . Middendorfiana, clear yellow, June and July, $3 \mathrm{ft}$. Orangeman, orange-yellow, July and August, 2 to 3

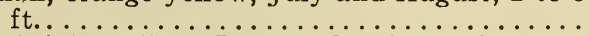

Sieboldi, bright yellow, June to October, $3 \mathrm{ft} . \ldots$. Thunbergii, bright yellow, June and July, 2 to $3 \mathrm{ft}$.

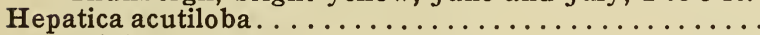

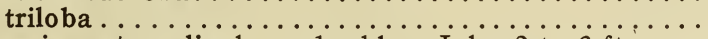

Hesperis matronalis, lavender-blue, July, 2 to $3 \mathrm{ft}$......

Heuchera Brizoides, bright pink, July and August, 18 in. sanguinea, crimson-yellow, all summer, 6 to 8 in.....

Hibiscus moscheutos, pink, August, $5 \mathrm{ft} . . . . . . . .$. var. Crimson Eye, August and September. $5 \mathrm{ft} . .$. . Marvel Mallows, red, white and pink...........

Hieracium aurantiacum, orange-red, June to October, 8

Hollyhock (See Althaea rosea)

Humulus lupulus (Hop-Vine) 2 years ............

Hysopus officinalis (Hyssop) 1 to $11 / 2 \mathrm{ft} . \ldots \ldots \ldots \ldots . . . . . .$.

Iberis sempervirens (Candytuft) white, May and June,

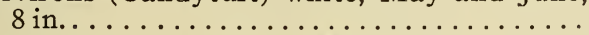

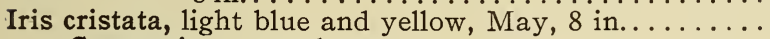

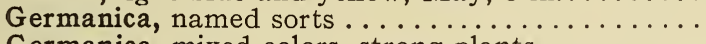

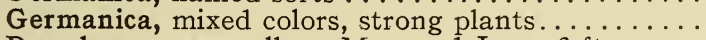

Pseudo-accorus, yellow, May and June, $3 \mathrm{ft} . . . .$.

Pumila Cyanea, rich purple, May, 6 to 8 in.......

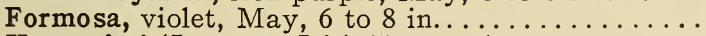

Kaempferi (Japanese Iris) 30 named sorts .........

Sibirica, light blue, July, $3 \mathrm{ft} . . \ldots \ldots \ldots \ldots \ldots \ldots \ldots \ldots \ldots$

Snow Queen, white, July, 2 to $4 \mathrm{ft} . . \ldots \ldots \ldots \ldots \ldots$ Per 10

Per 100

$\$ .60$

$\$ 4.00$

.60

4.00

.60

4.00

1.20

10.00

.60

5.00

1.00

8.00

1.00

6.00

.60

4.00

1.00

8.00

.50

4.00

2.00

.80

.80

6.00

6.00

$1.50 \quad 12.00$

$.50 \quad 4.00$

$.90 \quad 7.00$

.70

.90

6.00

7.00

.70

6.00

.60

5.00

$.60 \quad 5.00$

1.00

1.00

.80

1.00

.80

6.00

.80

.80

2.00

6.00

6.00

6.00

$.60 \quad 4.00$

$1.00 \quad 8.00$

$.75 \quad 5.00$

$.80 \quad 6.00$

$1.20 \quad 10.00$

$.80 \quad 6.00$

$.60 \quad 4.00$

$.90 \quad 7.00$

$1.00 \quad 7.00$

$1.00 \quad 7.00$

$1.20 \quad 10.00$

$1.00 \quad 7.00$

$.60 \quad 5.00$

$.80 \quad 6.00$

$.80 \quad 5.00$

Lathyrus latifolius, pink and red, July to September, $4 \mathrm{ft}$..

Lavendula vera (Lavender) July to September, $2 \mathrm{ft.....}$

Lepachys pinnata (yellow). 
HARDY HERBACEOUS PERENNIALS, ETC.-(Continued)

Liatris odoratissima, purple, August and September, 2

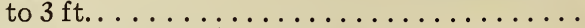

pycnostachya, pale purple, August and September, $4 \mathrm{ft} . . . \ldots \ldots \ldots \ldots \ldots \ldots . . . \ldots \ldots$.

Scariosa, lavender-blue, August and September, $2 \mathrm{ft}$.

Lilium auratum, white and crimson, July and August, 3

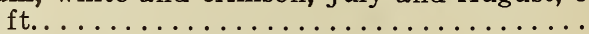

Batemanni, apricot-yellow, July, $3 \mathrm{ft} . \ldots \ldots \ldots \ldots$

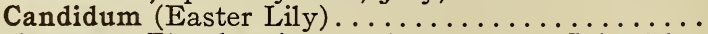
elegans or Thunbergianum, deep maroon, July, $3 \mathrm{ft}$. speciosum album, white, August and September, $3 \mathrm{ft}$. var. rubrum, white, spotted crimson, August and

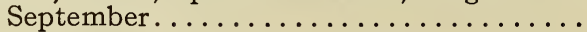
superbum, yellowish-red, July, 3 to $4 \mathrm{ft} . . . \ldots \ldots$. tigrinum (Tiger Lily) August, $4 \mathrm{ft} . . \ldots \ldots \ldots \ldots \ldots$ var. flore pleno, double, August, $4 \mathrm{ft} . \ldots \ldots \ldots \ldots$.

Linum flavum (Flax) . . . . . . . . . . . . . .

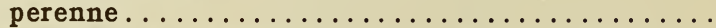
$\$ 1.00$ $\$ 8.00$

1.00 8.00 $1.00 \quad 8.00$

1. $20 \quad 10.00$

$1.20 \quad 10.00$

$1.20 \quad 10.00$

$1.20 \quad 10.00$

$1.50 \quad 12.00$

$1.50 \quad 12.00$

$1.00 \quad 8.00$

$.80 \quad 6.00$

$1.00 \quad 8.00$

$1.00 \quad 7.00$

$.80 \quad 6.00$

Lobelia cardinalis, scarlet, August and September, ...... coerulea or syphilitica, deep blue, September, $3 \mathrm{ft}$... .

Lupinus polyphyllus, deep blue, June and July, $3 \mathrm{ft}$.... alba, white, June and July, $3 \mathrm{ft} . \ldots \ldots \ldots \ldots \ldots$. . . .

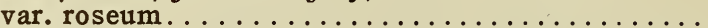

Lychnis Chalcedonica (London Pride) crimson, June to August, $3 \mathrm{ft} . \ldots \ldots \ldots \ldots \ldots \ldots \ldots$ plenissima semperflorens, pink, all summer, 18 in. Haageana, brilliant scarlet, July and August, 12 in. viscaria splendens plena (Ragged Robin) fiery rose,

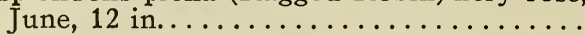

Lysimachia nummularia (Money-wort), yellow, June to

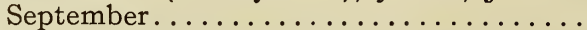
clethroides, white, June and July, 2 to $3 \mathrm{ft} . \ldots \ldots$. Lythrum roseum superbum, bright rose, July to September, $4 \mathrm{ft} . \ldots \ldots \ldots \ldots \ldots \ldots \ldots$.

Malva moschata, rose, June to September, $2 \mathrm{ft} . . . \ldots \ldots$ alba, white, June to September, $2 \mathrm{ft} . \ldots \ldots \ldots \ldots$.

Mellisa officinalis (Balm) $1 \mathrm{ft} . \ldots \ldots \ldots \ldots \ldots \ldots \ldots$

Mentha viridis (Spearmint) $1 \mathrm{ft} . \ldots \ldots \ldots \ldots \ldots \ldots$ piperita (Peppermint) $1 \mathrm{ft} . \ldots \ldots \ldots \ldots \ldots \ldots$

Mertensia Virginica, 18 in. . . . . . . . . . . . . .

Monarda didyma, deep rose, June to September, $3 \mathrm{ft}$. hybrida, scarlet, June to September, $3 \mathrm{ft} . . . \ldots \ldots$. . fistulosa, purplish-rose, June to September, $3 \mathrm{ft} . .$. alba, white, June to September, $3 \mathrm{ft} . . . . . . . . .$.

Myosotis palustris (The True Forget-me-not) light blue, all summer, 6 in.................

Oenothera macrocarpa, or O. Missouriensis, deep yellow,

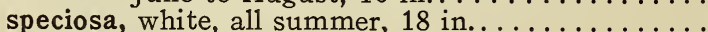


HARDY HERBACEOUS PERENNIALS, ETC.-(Continued)

Papaver nudicaule, bright yellow, all summer, 8 in....

Per 10

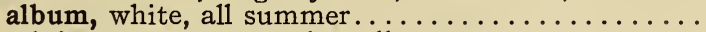
miniatum, orange-scarlet, all summer.......... orientalis, crimson-scarlet, June, $2 \mathrm{ft} . . \ldots \ldots \ldots \ldots$

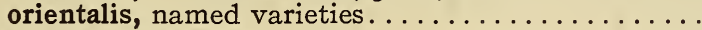

Pardanthus Sinensis, orange, spotted black, July and

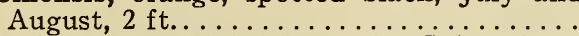

Pentstemon barbatus Torreyi, bright scarlet, July, $4 \mathrm{ft}$. . digitalis, pure white, July and August, $3 \mathrm{ft} . \ldots \ldots$. diffusus, purple, June and July, 18 in........... grandiflorus, reddish-purple, June and July, $3 \mathrm{ft} .$. . ovatus, purple, July and August, $3 \mathrm{ft}$. . . . . . . . . Phalaris arundinacea variegata (Ribbon Grass) $21 / 2 \mathrm{ft}$... Phlox amoena, deep pink, April and May, $1 \mathrm{ft} . . . . .$. . Caroliniana ovata, purplish-red, $1 \mathrm{ft} . . . \ldots \ldots \ldots$ decussata, 50 named sorts, all colors, $3 \mathrm{ft}$. (See

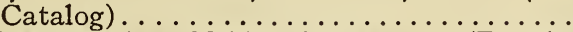

New and Choice Varieties of Phlox decussata. (For description see General Catalog.)

Phlox Elizabeth Campbell. . . . . . . . . . . . . . .

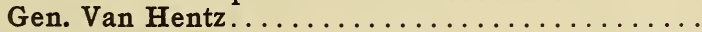

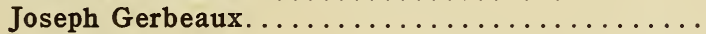

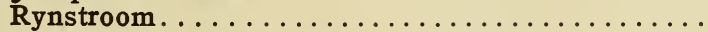

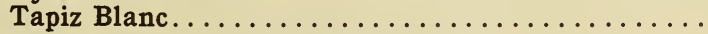

Stellaria, pale lilac, April and May, 5 to 6 in...... subulata, purple-pink, April and May, 4 to 6 in.... alba, white, April and May, 4 to 6 in........... The Bride, white with red center, April and May. . violacea, bright red, 4 to 6 in................ suffruticosa, Miss Lingard, white, June to October,

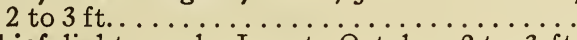

Indian Chief, light purple, June to October, 2 to $3 \mathrm{ft}$.

Physostegia Virginica, pink, July and August, 1 to $2 \mathrm{ft}$... . alba, white, July and August, 1 to $2 \mathrm{ft} . . . \ldots \ldots$

Pinks, Hardy Garden Varieties (See Dianthus).........

Platycodon grandiflora, deep blue, July to October, $2 \mathrm{ft..}$.

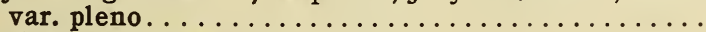

Plumbago larpentae (Blue Leadwort) . . . . . . . . . .

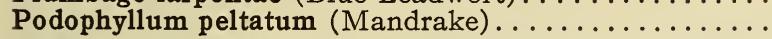

Polemonium caeruleum, light blue, May to July, 18 in. . . reptans, bright blue, April to June, 6 in..........

$\$ .60$

.60

.60

.80

1.00

Per 100

1.00

.80

.80

.80

.80

.80

.60

.60

1.00

$\$ 5.00$

5.00

5.00

6.00

8.00

.80

6.00

5.00

7.00

6.00

6.00

4.00

4.00

8.00

1. 50

1. 20

1.00

1.00

1.50

5.00

1.00

Polygonatum commutatum (Solomon's Seal) white, May,

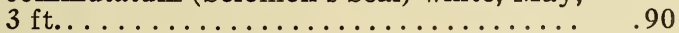
multiflorum, white, May and June, $3 \mathrm{ft} . \ldots \ldots \ldots$

Polygonum cuspidatum, white, August and September, 6

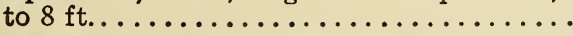

Primula officinalis hybrida, various colors, April and

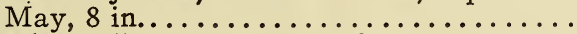

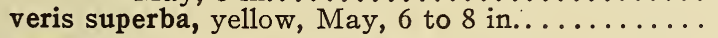

Pyrethrum balsamita (Chrysanthemum balsamita). The old-fashioned Costmary or Mint-Geranium ..' roseum, single, all colors, May and June, $1 \mathrm{ft} . . . .$. . roseum, double varieties, white, pink and red. .... 
HARDY HERBACEOUS PERENNIALS, ETC.-(Continued)

Ranunculus acris flore plena, golden yellow, May to September, $2 \mathrm{ft.} . \ldots \ldots \ldots \ldots \ldots \ldots \ldots \ldots$

repens, double yellow, June and July, 8 to 10 in...

Rhexia Virgvinica, crimson, July to September, 8 to 10 in.

Rudbeckia var. Golden Glow, double yellow, July to Sep-

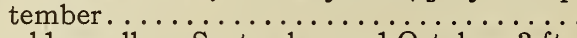

Newmanii, golden yellow, September and October, $3 \mathrm{ft}$. purpurea (Echinacea) August and September, $3 \mathrm{ft}$. . .

sub-tomentosa, lemon-yellow, August, $5 \mathrm{ft} . . . \ldots$. .

Ruta graveolens (Rue) $2 \mathrm{ft} . \ldots \ldots \ldots \ldots \ldots \ldots \ldots \ldots$

Salvia pratense, deep blue, June and July, 2 to $3 \mathrm{ft}$....

officinalis (Sage) $2 \mathrm{ft} . \ldots \ldots \ldots \ldots \ldots \ldots \ldots$. . . . . . . . .

Sanguinaria Canadensis (Blood-root) white, April, $1 \mathrm{ft}$..

Santolina incana, yellow, July and August, $11 / 2$ to $2 \mathrm{ft}$.

Saponaria officinalis flore pleno, double pink, August, 2

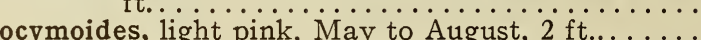

Saxifraga cordifolia, deep rose, April and May, 12 to 18

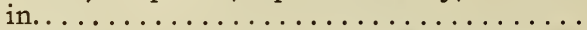

Per 10

Per 100

$\begin{array}{rr}\$ .60 & \$ 4.00 \\ .60 & 4.00 \\ .80 & 6.00 \\ & \\ .80 & 6.00 \\ .80 & 6.00 \\ .80 & 6.00 \\ .80 & 6.00 \\ 1.00 & \\ .90 & 7.00 \\ .90 & 6.00 \\ .80 & 6.00 \\ .80 & 6.00 \\ .80 & 6.00 \\ 1.00 & 8.00\end{array}$

Scabiosa Caucasica, lilac-blue, July to September, 12 to

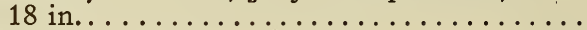

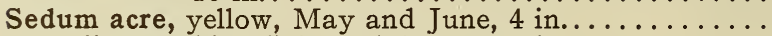

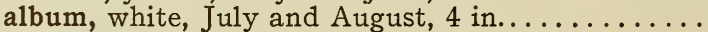

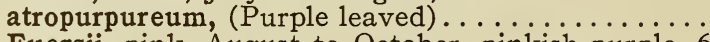

Euersii, pink, August to October, pinkish-purple, 6

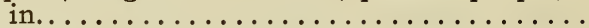

Kamschaticum, golden yellow, June and August,

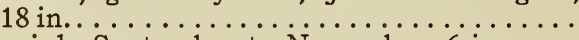

Sieboldii, pink, September to November, 6 in....... spectabile, pink, September to November, 18 in... . var. purpureum (Deep rose and early) ..........

Stolonifera, purple, July and August, 6 to 8 in.....

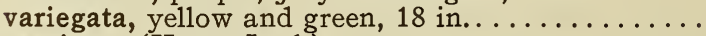

Sempervivum (House Leek) . . . . . . . . . . . . . . . . .

Shasta Daisy (See Chrysanthemum leucanthemum)....

Solidago rigida (Golden Rod) yellow, July to October, 4

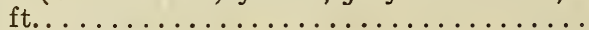

Spiraea aruncus Kneifferi, white, June and July, 3 to 4

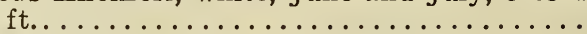

astilboides, white, June and July, $2 \mathrm{ft} . \ldots \ldots \ldots . . . . .$.

var. floribunda, white, June and July, 2 to $3 \mathrm{ft}$.....

Chinensis, pink, July and August, $1 \mathrm{r} / 2 \mathrm{ft} . . . \ldots \ldots$

Davidii, rose-pink, June and July, 3 to $4 \mathrm{ft} . . . \ldots$.

filipendula flore pleno, double white, July and Aug-

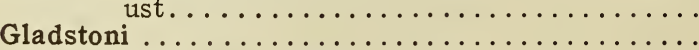

Japonica, white, June and July, $2 \mathrm{ft} . \ldots \ldots \ldots \ldots$

Queen Alexandra, deep pink, June and July, $2 \mathrm{ft} .$. .

Stachys lanata, silvery foliage, purple, July, $2 \mathrm{ft} . . . . .$.

Statice latifolia, bright blue, July to September, $2 \mathrm{ft} . .$.

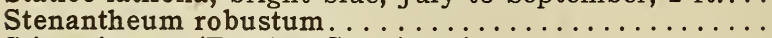

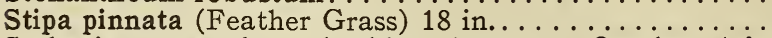

Stokesia cyanea, lavender-blue, August to October, $1 \mathrm{ft}$.

alba, white, August to October, $1 \mathrm{ft} . \ldots \ldots \ldots \ldots$.

1.00

.60

.60

1. 20

5.00

5.00

.80

10.00

.60

6.00

1.00

4.00

.80

8.00

1.00

5.00

.80

7.00

.70

1.00

5.00

.70

4.00

.80

5.00

1.50

6.00

1.00

12.00

1.00

8.00

1.00

8.00

1.50

8.00

1.00

1.50

1.00

1.50

.80

.80

2.00

1.00

.80

7.00

12.00

7.00

10.00

6.00

6.00

15.00

8.00

.80

5.00

1. 20

6.00

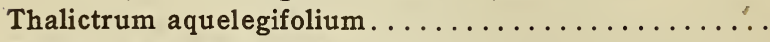

Thermopsis Caroliniana, yellow, June and July, $3 \mathrm{ft....} \mathrm{.}$

1.00

10.00

“ mollis, yellow, May to August, $3 \mathrm{ft} . . . .$. .

1.00

7.00

7.00 
HARDY HERBACEOUS PERENNIALS, ETC.-(Continued)

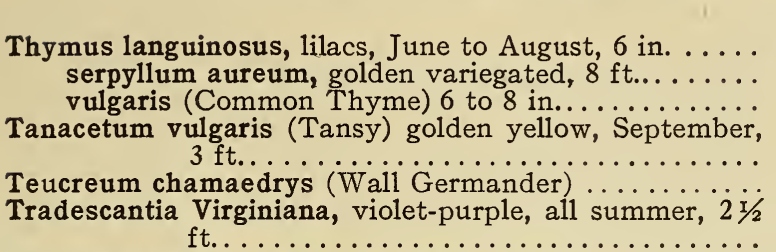

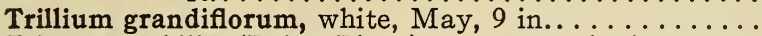

Tritoma nobilis (Poker-Plant) orange, red, August to

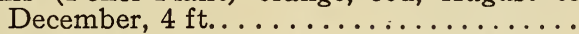

Pfitzerii, orange-scarlet, August to October, $4 \mathrm{ft} . .$. .

Trollius Europaeus, lemon yellow, all summer, $1 \mathrm{ft} . . .$. var. Orange Globe, deep orange, May and June, 1 to $1 \mathrm{r} / 2 \mathrm{ft} . \ldots \ldots \ldots \ldots \ldots \ldots \ldots \ldots \ldots$

Tunica saxifraga, rosy white, June to August, 6 in.....

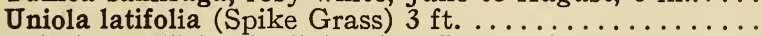

Valeriana officinalis, light blue, June, $4 \mathrm{ft} \ldots \ldots \ldots \ldots$.

Veronica amethystina, amethyst-blue, June, $1 \mathrm{ft} . . . .$. . . gentianoides, pale blue, May, $1 \mathrm{ft} . \ldots \ldots \ldots \ldots \ldots$. incana, deep blue, June and July, $1 \mathrm{ft} . . . \ldots \ldots . . . . .$. longifolia subsessilis, rich blue, August and Septem-

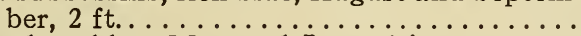

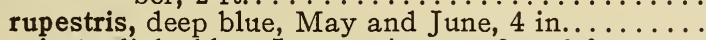
spicata, light blue, June to August, 2 to $3 \mathrm{ft} . . . . .$. Vernonia Novaborascensis (Ironweed) deep purple,

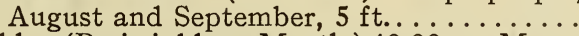

Vinca minor, blue (Periwinkle or Myrtle) 40.00 per $\ddot{M}$....

Viola cornuta, dark blue, all summer, 9 in . . . . . . . . . alba, white, all summer, 9 in. . . . . . . . . . . .

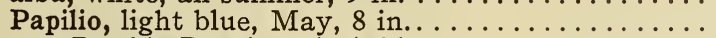
var. Double Russian, dark blue............. var. Wellsiana, dark blue..................

$\begin{array}{rr}\text { Per } 10 & \text { Per } 100 \\ \$ .80 & \$ 6.00 \\ .80 & 6.00 \\ .80 & 5.00 \\ & \\ .80 & 6.00 \\ 1.20 & 8.00\end{array}$

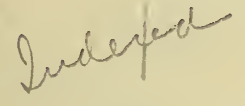

\section{Hardy Roses}

Hybrid Perpetuals and Hybrid Teas

Strong plants; $\$ 2.00$ per $10 ; \$ 15.00$ per 100 , except where noted. General List of Varieties

Alfred Colomb (H.P.) red

Per 10 Per 100

American Beauty (H.P.) deep rose

Anne de Diesbach (H.P.) clear rose

Baron de Bonstettin (H.P.) maroon

Baroness Rothschild (H.P.) pink

British Queen. (H.T.). Flowers pure white and of perfect form. One of the most beautiful white Roses existing. Each 50 cents.

Capt. Christy. Beautiful flesh color. ............ $2.50 \quad 20.00$

$\begin{array}{llll}\text { Caroline Testout (H.T.). Large, double, clear bright rose. } & 2.50 & 20.00\end{array}$

Clothide Saupert. (H.T.). Pearly white, but variable, the same plant often producing red and white

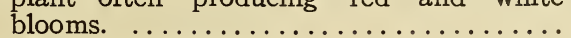

Coquette des Alps (H.P.) blush white

$2.50 \quad 20.00$

Dean Hole, (H.T.) silvery carmine, shade salmon (new)..

Duke of Edinburg (H.P.) crimson 


\section{HARDY ROSES-(Continued)}

Earl of Dufferin (H.P.) crimson

Per $10 \quad$ Per 100

Double Pink Killarney. (H.T.). A distinct improvement on the common Pink Killarney.............

Edward Mawley. (H.T.). Very deep carmine. Buds long and pointed. Free flowering and very excellent.

Farben Konigin, (H.T.) rosy carmine (new) ...........

Franz Deegan,(H.T.)golden yellow, pale yellow center (new)

Francis Levet (H.P.) cherry red

Frau Karl Druschki (H.P.) pure white $\ldots \ldots \ldots \ldots \ldots \ldots$

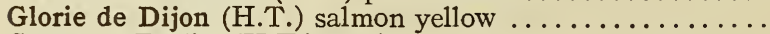

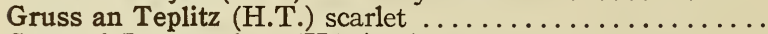

General Jacqueminot (H.P.) crimson

Harrison Yellow (Aus.) yellow

Hermosa. Bright rose, very double. ............

Hugh Dickson (H.P.) red

J. B. Clark, (H.T.) deep scarlet, shaded crimson (new) ..

John Hopper (H.P.) rose-carmine

Jonkheer J. L. Mock. (H.T.). Clear imperial pink, reverse of petals rosy, silvery white. Large blooms freely produced on stiff stems. Strong grower and very desirable. (Each 50 cents).

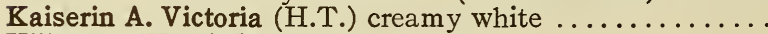

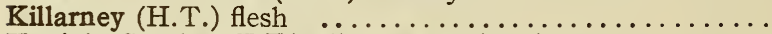

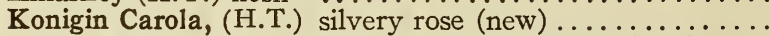

Lady Ashtown. (H.T.) pale rose, shaded yellow (new).....

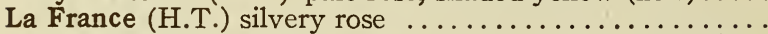

Lady Hillingdon. (H.T.). Deep golden yellow. Buds long and pointed. Very free flowering(Each $50 \mathrm{cts}$ ).

Lady Pirrie. (H.T.). A delightful garden Rose. Deep coppery salmon with apricot tinted center. (Each 50 cents).

Liberty (H.T.) crimson-scarlet

Louis Van Houtte (H.P.) scarlet

Lyon (The Lyon) salmon pink or coral red, shaded yellow

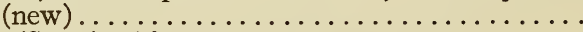

Mad. Plantier (Sum.) white

Mad. Gabriel Luizet (H.P.) pink

Mad. Caroline Testout (H.T.) pink.............

Mad. Charles Wood (H.P.)

Mabel Morrison (H.P.) white $\ldots \ldots \ldots \ldots \ldots \ldots \ldots$

Mad. Jules Grolez. (H.T.). Bright China Rose, large, full and perfect form. Very floriferous. (Each 50 cents).

Magna Charta (H.P.) crimson pink

Marshall P. Wilder (H.P.) cherry carmine

Margaret Dickson (H.P.) white

Maman Cochet. (H.T.). Clear carmine rose, salmon shaded.

Maman White Cochet. (H.T.). Sport from Maman Cochet.

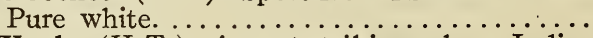

Mrs. Aaron Ward. (H.T.). A most striking color. Indian yellow, shaded to lemon yellow at edges of petals. Very large and full. (Each 50 cents).

Mrs. R. G. Sharman-Crawford. Color, deep rosy pink; flowers large and perfect; free bloomer. ....

Mrs. John Laing (H.P.) pink 


\section{Paul Neyron (H.P.) deep rose}

Perle Von Gettysburg, (H.T.) light yellow hybrid of $K$.

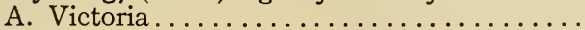

Persian Yellow (Aus.) yellow

Pharisaer, (H.T.) rosy white, shaded salmon (new) ......

Prince de Bulgaria, (H.T.) light pink, shaded salmon (new)

Prince Camille de Rohan (H.P.) velvety crimson

Richmond (H.T.) crimson

Rhea Reid, (H.T.) varying from rose cerise to rich crimson

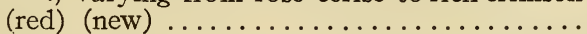

Soleil d'Or (H.P.) gold and orange $\ldots \ldots \ldots \ldots \ldots \ldots \ldots \ldots$

Souv. de Malmaison (B.C.) flesh . . . . . . . . . . . . . . .

Sunburst. (H.T.). Orange yellow, with deeper center. Long, pointed buds. Very free flowering. (Each 50 cents).

\section{Ulrich Brunner (H.P.) dark red}

Viscountess Enfield (H.T.) (Golden pink, shaded carmine), each 50 cents.

William Allen Richardson (C.T.) yellow ........... 3.00

York and Lancaster. Striped, red and white. Very old, yet much sought.

$2.50 \quad 20.00$

MOSS ROSES

Blanche Moreau, pure white $\ldots \ldots \ldots \ldots \ldots \ldots \ldots$

Crested Moss, deep pink . . . . . . . . . . . . . . . . . .

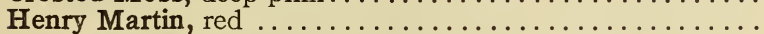

Princess Adelaide, pale rose $\ldots \ldots \ldots \ldots \ldots \ldots \ldots \ldots \ldots \ldots$

Salet Moss, light rose

\section{CLIMBING, RAMBLER AND TRAILING ROSES}

Climbing American Beauty, each 50 cents.

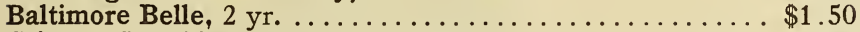

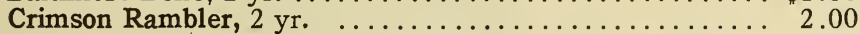

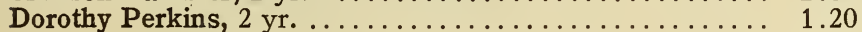

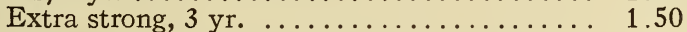

Excelsa (A red or scarlet Dorothy Perkins) ......... 3.00

Flower of Fairfield (new) 2 yr................ 5.00

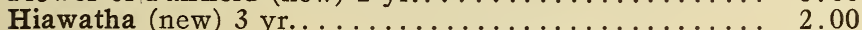

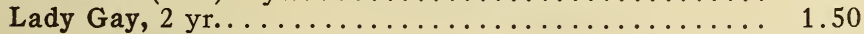

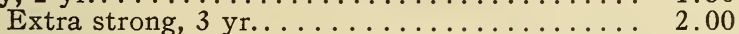

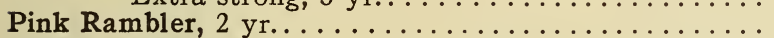

1.50

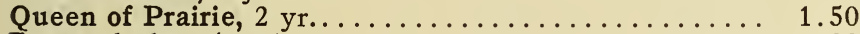

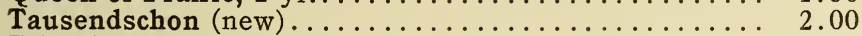

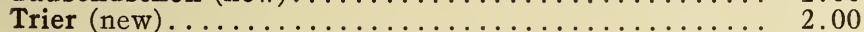

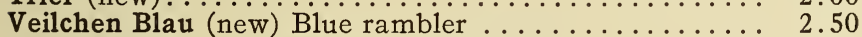

$\$ 12.00$

15.00

10.00

12.00

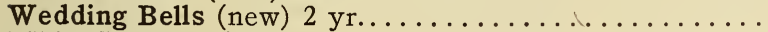

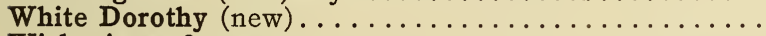

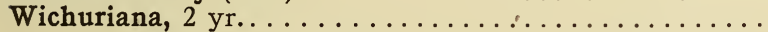

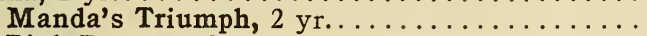

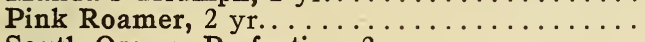

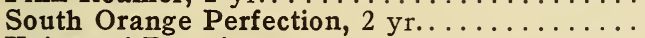

Universal Favorite, 2 yr..............

Yellow Rambler, 2 yr.

\section{ROSA RUGOSA AND HYBRIDS}

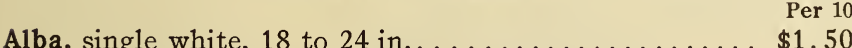




\section{HARDY ROSES-(Continued)}

Blanche de Coubert, double white.............\$2.50

Conrad F. Meyer, double pink. ................ 2.00

Hansa, double red..................... 2.00

Madam George Bruant, double white.......... 2.00

New Century, bright rosy pink (new) . . . . . . . 2.50

Trailing Rugosa, single pink. ...................... 6.00

Rubra, single red, 18 to 24 in. .............. 1.00

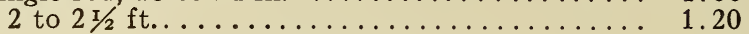

Per 100

$\$ 15.00$

15.00

15.00

8.00

10.00

\section{HYBRID SWEET BRIAR}

Amy Robsart, deep rose. . . . . . . . . . . . . . $\$ 2.50$

Anne of Geirerstein, deep crimson. . . . . . . . . 2.50

Flora McIvor, pure white. .............. 2.50

Meg. Merrilies, crimson. ................ 2.50

Rosa Bradwardine, clear rose. . . . . . . . . . . 2.50

\section{BABY RAMBLERS}

Baby Dorothy, bright pink . . . . . . . . . . . . \$2.00

Mad. N. Levasseur, crimson. . . . . . . . . . 2.00

Mrs. Wm. H. Cutbush, cherry pink (new) .......... 2.00

Katherine Zennett, white.

STANDARD ROSES, OR ROSES IN TREE FORM

We offer the following varieties of Roses grafted on straight stems.

John Hopper.

Paul Neyron.

Killarney.

F. K. Druschki. Magna Charta. Ulrich Brunner. Grus an Teplitz. K. A. Victoria. Price: Each 50 cents. Per $10, \$ 4.50$

General Jacqueminot.

Mrs. Jno. Laing.

Mad. Gab. Luizet.

Crimson Rambler.

Dorothy Perkins.

Pink Baby Rambler.

Crimson Baby Rambler.

\section{Fruit Department}

\section{STANDARD APPLES}

1 year old. $31 / 2$ to $41 / 2 \mathrm{ft}$. high

2 year old. 5 to $7 \mathrm{ft}$. high

Varieties Bellefleur, Ben Davis, Early Harvest, Fameuse, Golden Russet, Hubbardston's, Pound Sweet, Rome Beauty, Stark, Talman Sweet, Wine Sap. Baldwin, Duchess, Gilliflower, Gravenstein, McIntosh Red, Northern Spy, Wealthy, Opalescent, Porter, William's Favorite, Wolf River, Yellow Transparent.

Crab Apples, first grade.

Hyslop, Martha, Transcendent, Whitney.

Dwarf Apples, 3 to $4 \mathrm{ft} . . . \ldots \ldots \ldots \ldots \ldots \ldots \ldots \ldots \ldots$. . . . . . Greening, Duchess, Seek-no-further, Gravenstein, Wealthy.

STANDARD PEARS

$\begin{array}{rc}\text { Per } 10 & \text { Per } 100 \\ \$ 1.00 & \$ 8.00 \\ 3.00 & 25.00 \\ 5.00 & 40.00\end{array}$

First grade 


\section{FRUIT DEPARTMENT-(Continued)}

Bartlett, Beurre d'Anjou, Duchess, Flemish Beauty, Kieffer, Howell, Lawrence, Manning's, Sheldon, Seckel, Vermont Beauty, Wilder.

Beurre Clairgeau, Clapp's Favorite, Worden Seckel.

Beurre Bosc.................\$7.50

Dwarf Pears, $3 / 4$ in., first class. . . . . . . . . . . 2.50

Bartlett, Beurre d'Anjou, Clapp's Favorite,

Duchess, Lawrence, Seckel.

\section{FAN TRAINED FRUIT TREES}

We offer a limited number of Apples and Pears, in handsome fantrained stock and in leading varieties.

Price: $-\$ 2.00$ to $\$ 2.50$ each.

Pyramid trained Apples and Pears in leading varieties and on dwarf stock. Each $\$ 2.00$.

\section{CHERRIES}

First grade . . . . . . . . . . . . . . . . . \$3.50

$\$ 30.00$

Black Eagle, Black Tartarian, Early Richmond,

Gov. Wood, Montmorency, English Morello,

Rockport, Windsor, Yellow Spanish, Napoleon.

\section{PEACHES}

First grade

Belle of Georgia, Crawford's Early, Crawford's

$\$ 12.00$

Late, Champion, Crosby, Carman, Elberta,

Fitzgerald, Foster, Greensboro, Mt. Rose, Ni-

agara, Stump, Steven's Rarepipe, Triumph.

\section{PLUMS}

First grade, 6 to $7 \mathrm{ft} . \ldots \ldots \ldots \ldots \ldots \ldots \ldots \ldots \ldots \ldots$

Abundance, Burbank, Climax, Coe's Golden

Drop, German Prune, Green Gage, Lombard,

Red June, Damson.

\section{QUINCES}

First grade, 4 to $5 \mathrm{ft} . \ldots \ldots \ldots \ldots \ldots \ldots \ldots \ldots \ldots$

Champion, Meeche's, Bourgeat, Orange, Rea's Mammoth.

\section{APRICOTS}

3 to $4 \mathrm{ft}$, in variety............ \$2.50

\section{NECTARINES}

3 to $4 \mathrm{ft}$, in variety ............. $\$ 2.50$ 


\section{FRUITT DEPARTMENT-(Continued)}

Grapes, 2 and 3 yr.

GRAPES

Agawam

Per 10

- Per 100

Brighton

$\$ 1.20$

Campbell

1.20

$\$ 10.00$

Concord

2.50

10.00

Delaware.

1. 20

20.00

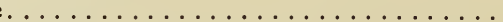

1.20

10.00

Green Mountain

3.00

10.00

Moore's Diamond

1. 20

Moore's Early.

1.20

Niagara.

1. 20

Salem.

1. 20

Vergennes.

1. 20

Worden

1. 20

25.00

10.00

10.00

10.00

10.00

10.00

10.00

\section{CURRANTS}

Currants, 2 yr., No. $1 \ldots \ldots \ldots \ldots \ldots \ldots \ldots \ldots . \ldots$......... $\$ 0.80$ $\$ 6.00$

Cherry, Fay's Prolific, Le Versailles, Lee's Black, White Grape, Wilder.

Perfection (Largest red).

\section{GOOSEBERRIES}

Gooseberries, strong, 2 and $3 \mathrm{yr}$.
Downing
$\$ 1.00$
$\$ 8.00$
Houghton.
1.00
Industry
1.50
8.00
White
Pearl.
2.00
12.00
1.50

Raspberries, first class:

\section{RASPBERRIES}

Black Diamond. . . . . . . . . . . . . . . . . . \$0.50

Columbian....................

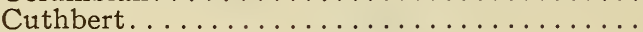

Cumberland.

Golden Queen. . . . . . . . . . . . . . . .

Marlboro.

Loudon.

50

St. Regis Everbearing Red Raspberry

1.00

BLACKBERRIES

Blackberries, first class:

Agawam.

$\$ 0.50$

Eldorado

Erie

Rathbun

3.00

Snyder.

Wachusett

3.00

.50

3.00

Asparagus, 2 yr., strong.

Conover's Colossal, $\$ 6.00$ per M.........

Palmetto, $\$ 6.00$ per $\mathrm{M}$.

Giant Rust Proof

Rhubarb, 2 yr., No. 1. 


\section{GOLD MEDAL}

ansarded

The New England Nurseries Co.

for Deciduous Shrubs and Evergreens

\section{SILVER MEDAL}

$$
\text { awarded for }
$$

Herbaceous Perennials

- EXHIBITED AT PAN AMERICAN EXPOSITION SAN FRANCISCO, CALIFCRNIA, 1915.

"BEDFORD GROWN" MEANS QUALITY 
L. E. Crosscut Co., Printers, Boston, Mass. 


\section{Approximate Express and Freight Rates on Nursery Stock to Principal Shipping Points}

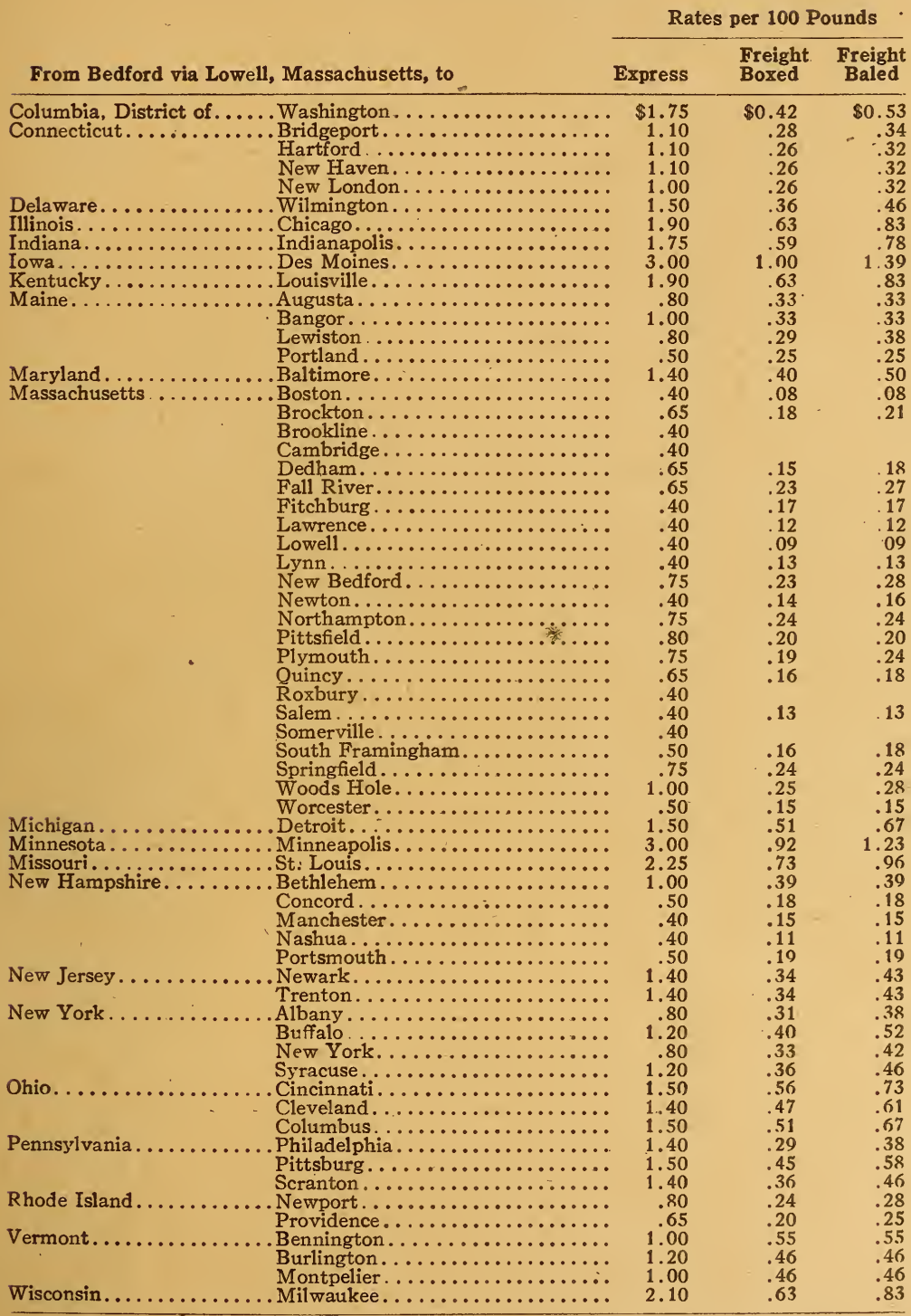

When stock is shipped by freight via Boston. there will be a charge for transferring across the city. in addition to above freight rate. 


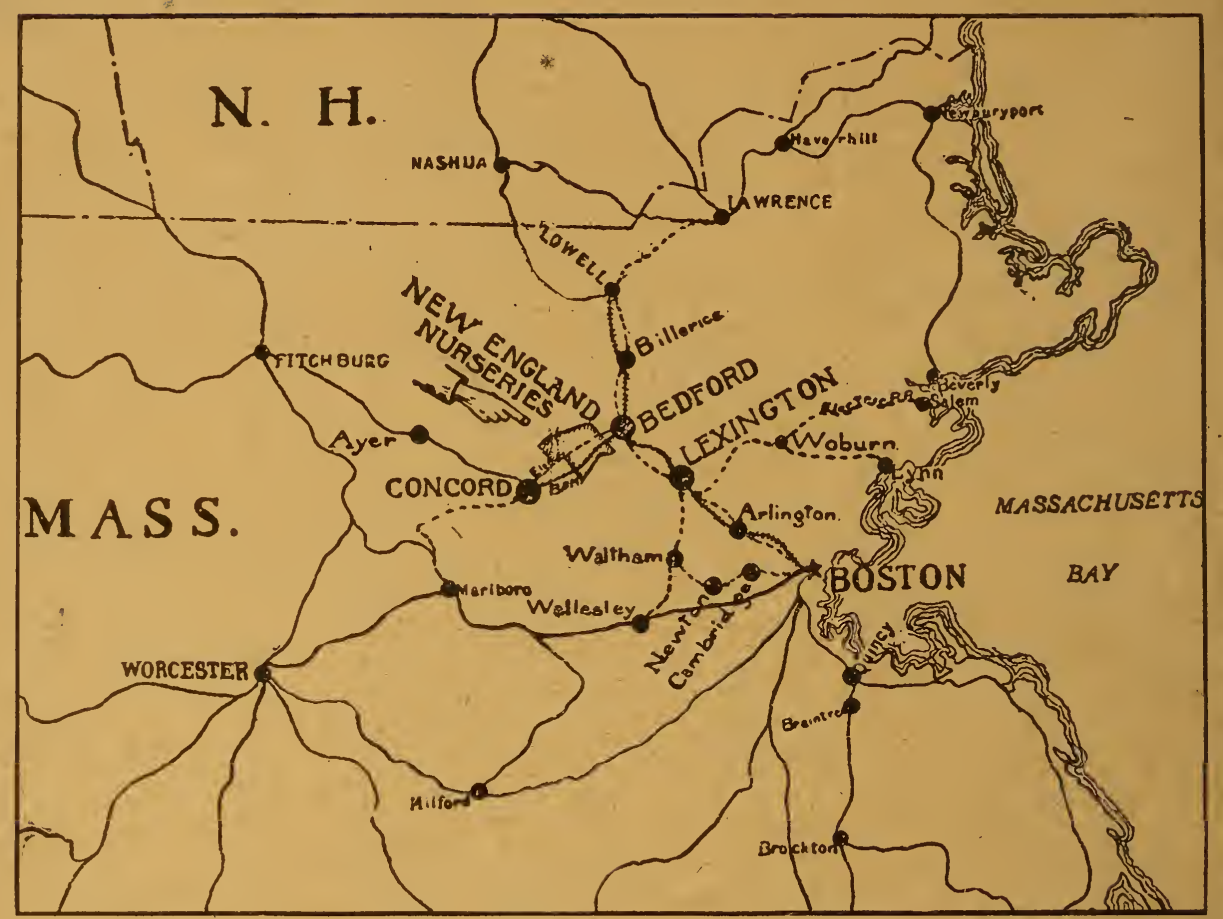

LOCATION OF THE NEW ENGLAND NURSERIES

Concord electric cars, leaving Arlington Heights every half hour, pass directly through our grounds. Trains on Boston \& Maine R. R., leaving North Station, Boston, stop at our office door. Purchase ticket for Shady Hill station, Bedford, Mass.

\section{The NEW ENGLAND NURSERIES CO.}

\section{BEDFORD, MASSACHUSETTS}

Telephone, Lexington 274 